\title{
Indian Software Capital: Sociography of a New Entrepreneurial Elite
}

Roland Lardinois

\section{OpenEdition}

\section{Journals}

\section{Electronic version}

URL: http://journals.openedition.org/samaj/4309

DOI: $10.4000 /$ samaj.4309

ISSN: $1960-6060$

\section{Publisher}

Association pour la recherche sur l'Asie du Sud (ARAS)

\section{Electronic reference}

Roland Lardinois, «Indian Software Capital: Sociography of a New Entrepreneurial Elite », South Asia Multidisciplinary Academic Journal [Online], 15 | 2017, Online since 31 March 2017, connection on 02 May 2019. URL : http://journals.openedition.org/samaj/4309 ; DOI : 10.4000/samaj.4309

This text was automatically generated on 2 May 2019.

\section{(c) (i) () $\Theta$}

This work is licensed under a Creative Commons Attribution-NonCommercial-NoDerivatives 4.0 International License. 


\title{
Indian Software Capital: Sociography of a New Entrepreneurial Elite
}

\author{
Roland Lardinois
}

This research was conducted in part in collaboration with Jules Naudet whose work focuses on the top 100 Indian companies listed on the NSE; the selection of the companies studied was carried out by Guillaume Tzelepoglou while Vasundhra Srivastava contributed to the collection of the data. I am grateful to Vena S. Kulkarni, Professor of Sociology, Arkansas State University, who has identified the caste origin of the managers through the study of their familys' names. A preliminary analysis of the data was carried out by Kenza Haouche, from the ENSAE, Paris, using " $R$ " software; the final analysis was elaborated by the author; Mathieu Ferry has always been helpful in answering my questions. This paper owes much to the three anonymous reviewers who helped me to clarify my point even if I have not been able to resolve all their queries. Finally I want to thank Praveen Singh Bhada who introduced me to Pramod Maheshwari at Career Point, Kota (Rajasthan).

\section{Introduction}

1 The Information Technology (IT) and IT Enabled Services (ITES) ${ }^{1}$ or to put it simply the software industry is a newcomer in the economic history of India. If we consider the year the hundred major IT companies went public, being listed at the National Stock Exchange (NSE), $83 \%$ of them (see below) were founded after 1985. Yet today the economic weight of this industry is quite impressive. According to NASSCOM, the premier professional trade body for the software industry, the Indian share of the worldwide IT market more than doubled from $24 \%$ in 2002 to $55 \%$ in 2015 (NASSCOM 2015). This Indian industry was estimated to account for revenues of 146 billion US dollars in 2015, and the annual growth rate has risen from $1.2 \%$ in 1998 to $6.4 \%$ in 2011 and to $12.3 \%$ in 2015 . At the mid-term of the second decade of the $21^{\text {st }}$ century, the direct workforce included 3.5 million 
employees and affected over 10 million indirect jobs, while the relative share of the sector amounted to $9.5 \%$ of the Gross Domestic Product of India.

Although the history of the software industry in India dates back to the early 1950s, this sector became important more than thirty years later when the government changed its economic policy in the last two decades of the $20^{\text {th }}$ century (Parthasarathy 2004; Sharma 2009, 2015). In 1991, the monetary crisis and the situation of quasi bankruptcy of the State triggered a major shift in economic policy. Devaluation of the rupee, deregulation of the economic market, liberalization of international trade, opening up to foreign investments, privatization of the companies and reforms in their governance, all these changes marked a major break in the Indian economy: it shifted from the importsubstitution policy led by the State to a new economic era which made possible the development of private industry that benefited the IT sector in particular. This is the reason why, by and large, the entrepreneurs who set up IT companies from the 1980s onwards can be considered as new entrants in the Indian economy, with some qualifications: firms like Tata Consultancy Services (TCS), Reliance Communications, TVS Electronics or Hinduja Solutions, to name a few, are the offshoots of larger industrial groups. Yet, we can hypothesize that even in these particular cases the managers who entered the new IT sector had qualifications that are different from those of the managers who worked for a long time in more traditional economic sectors.

The software industry has been the subject of a great number of studies conducted by economists (Heeks 1996; Arora and Athreye 2002; Saith, Vijayabaskar and Gayathri 2008), social anthropologists (Upadhya and Vasavi 2008; Lardinois and Illavarasam 2014; Upadhya 2016) and geographers (Leducq 2009). But we know little about the entrepreneurs and the companies who are the main actors of these changes. This article intends to partly fill this gap by focusing on Indian software capital considered as the nexus of firms and entrepreneurs which make up the core of the software industry. It is structured in five sections. First, I review some studies that deal with the software industry in order to clarify the aim of my research. Second, I detail the sources, data and methodology used in the survey, before analyzing, in the third part, the social space of software capital. In the fourth part, I describe the 3 clusters that constitute Indian software capital and in the fifth and last part I discuss the caste background of the top managers. The conclusion addresses some limitations of this study.

\section{Studying the software industry}

\section{A nebulous milieu?}

First, let us see how social scientists have analyzed this services sector. I will consider mainly two issues: the economic structure of the software companies and the sociodemographic profile of its entrepreneurs with a side issue, the caste background of the top managers of this industry. ${ }^{2}$

5 According to a report of the Software Technology Park of India (STP) a State agency in charge of facilitating the services required by the industry, IT companies are divided into three main categories: first, small and medium enterprises, second, major Indian companies with exports above three crores (10 million) rupees and third, Indian multinationals with foreign equity participation. At the beginning of the $2000 \mathrm{~s}, 53 \%$ of the 275 companies registered with the STP at Bangalore belonged to this third category 
(Upadhya 2004:5151). In her book Engineering India, Carol Upadhya recasts these three categories in order to define "software capital." She distinguished 3 groups: first, the national companies, referring to "Indian companies founded by local entrepreneurs with indigenous capital," second the foreign multinational, and third the transnational firms (Upadhya 2016:48-49). These last firms are called transnational or cross-border firms because, although they are registered in the US as they are financed by Non-Resident Indians (NRI), and venture capitalists often based in California, they operate in India through their subsidiaries. The chief managers of these cross-border firms constitute a "transnational capitalist class," a class of people which is the product of the globalization of the IT market in which they operate (Upadhya 2016:62-66). This classification is mainly based on the location of the registration of the software companies, opposing Indian versus foreign firms, but it does not say much about the social origins and the sources of the IT capital, information which could draw distinctions between the national firms constituting the major segment of the industry. Regarding Indian software companies Upadhya wrote that "entrepreneurs in the IT industry contrast their firm with "traditional family business"' (Upadhya 2016:37), but she does not engage with this statement in order to confront it with empirical data on the IT industry.

6 Two other studies conducted in Chennai have mentioned in passing IT-firm structure. John Harris, who interviewed 40 chief managers of 31 firms that belong to the top 500 IT companies in terms of market capitalization, stated: "the great majority of the software firms are fully Indian owned companies. A minority are collaborative ventures with European or American capital" (Harris 2003:330). Moreover added the author, almost all of these companies (28 out of 31 ) can be classified as "family business," a statement that contradicts the IT entrepreneurs interviewed by Upadhya at Bangalore. In their study of the Tamil Brahmans, C. J. Fuller and Haripriya Narasimhan also contrasted, on the one hand, the IT "family business" firms that are owned and controlled by the same family, and on the other hand the companies for which managers and owners are two distinct groups. Yet, none of these authors addressed the issues of the economic and social structure of the software companies.

7 The shareholding pattern of Indian corporates has been studied by many authors from a managerial viewpoint in order to assess its effect on the governance of the companies (Khanna and Palepu 2004, 2005; Jain 2006; Balasubramanian and Anand 2013; Tawiah and Benjamin 2014). Although the trend over the first decade of the $21^{\text {st }}$ century varies from one industrial sector to another, the authors agreed that the predominant shareholding pattern in India is concentrated ownership and control over the capital through the promoters group. This statement holds true for the software industry, wrote Tawiah and Benjamin, although their study is limited to the top 10 Indian IT companies. But it is confirmed by Khanna and Palepu who furthermore showed, on the basis of a survey of a thousand firms across different activities sectors, that "family-owned business groups ... can coexist with specialist firms focused on a particular industry," a point they have illustrated by contrasting TCS with Infosys (Khanna and Palepu 2004, 2005:284, 308-18). But all the authors, except the last ones, focused mainly on institutional and noninstitutional shareholders and do not consider other groups like national and foreign, or private and public shareholders, categories which are more relevant for characterizing the National software enterprises.

8 If the structure of the IT companies has not been much studied, it is also true that little is known about the socioeconomic background of the IT entrepreneurs. The common view 
is that the majority of these entrepreneurs have a "middle-class" background (although the definition of the "middle class" is a vexed issue) in terms of social origins and higher education. Yet Upadhya and Vasavi, who conducted a pioneering study of the IT sector in Bangalore in 2002-2003, wrote: "There has not been any large-scale survey of the social origins of Indian software entrepreneurs that could reliably confirm this assertion" (Upadhya 2004:5149). In the survey just mentioned, the cross-border firms seem overrepresented. These start-ups that are not listed on stock exchanges-at least in India -work on products, a particular niche of the software industry, while the core segment of this industry is concerned with projects and services. Furthermore, the chief managers of these start-ups clearly present a high sociodemographic profile: all the CEOs and many software entrepreneurs interviewed in Bangalore graduated from Indian Institutes of Technology (IIT), while this group accounts for less than one-quarter in our panel. The same bias towards the upper-middle classes characterizes the software engineers who work in these start-ups: half were Brahmans and three fourths from upper-caste groups, percentages higher than those we found among the chief managers of the major IT companies we studied.

9 The concentration of Brahmans in the software industry contrasts, it seems, with the well-known fact that Indian entrepreneurs, in general, still belong quite often to traditional merchant communities (Vaish ${ }^{3}$ like Agarwal or Marwari, Sindhi, Khatri, or Jains for example) whose families control the capital and the business of their firms (Chakraborthy 2011; Tripathi and Jumani 2013). Regarding this issue, Fuller and Narahsiman need to be quoted at length: "the endlessly repeated wisdom about Brahman overrepresentation in IT is really just a factoid, because nobody ever cites any figures to prove it. ... Actually, we too, are sure that Brahmans are overrepresented in the major IT companies. ... But let us acknowledge at this early stage that we will be unable to cite many figures to reinforce the qualitative evidence that we present (Fuller and Narasimhan 2014:22). Harris' general statement that the "the largest single group of the new software entrepreneurs [at Chennai] is constituted by Brahmans" would seem to reinforce Fuller and Narasimhan's point (Harris 2003:332), but it does not concur plainly with our data. Nevertheless both authors reviewed, who mainly used qualitative sources, agreed about the overrepresentation of the Brahmans and the high castes in the IT industry, and they both follow the same line of argument in order to explain this overrepresentation: the high level of education of the Brahmans, their long-standing mastery of the English language, as well as their urban ethos suffice to explain, more than their caste origin per se, they wrote, the heavy concentration of this elite group in the IT industry, which requires this particular kinds of skills and resources.

Yet the sociological analysis presented by these authors produces the feeling that neither the people interviewed nor the social scientists are fully comfortable in dealing with this issue, a sense of unease clearly expressed by Fuller and Narasimhan. That the caste diversity of the software industry is a sensible political subject should not refrain scholars from raising sociological questions that are often left aside: for example, the modes of recruitment and particularly the referral system, the mode of promotion, the selection of members of the board of directors, patronage and networking are some relevant subjects that should be addressed from an empirical viewpoint in order to extend our understanding of the grammar of caste in contemporary India (Deshpande 2011).

The studies reviewed have tended to paint a rather homogeneous picture of software companies, particularly national ones. Instead, we hypothesize that national software 
companies are differentiated both by their age (the period when they were founded), their economic structures, and the profiles of their top managers. In order to break with these impressionistic approaches of the IT sector, our analytic strategy has been to conduct a quantitative survey of software capital grounded on a panel of selected companies.

\section{Aims of the study}

Since its inception, one of the particularities of the software industry in India has been the close association between, on the one hand, the entrepreneurs who are predominantly engineers and scientists sharing the same technical education and, on the other hand, the IT enterprises they have founded, or have been closely associated with for the past decades, moving from one company to another as is illustrated by the career paths of IT managers. The software capital that is the subject of this study can be understood as the nexus of objectified socio-economic properties, resources and skills concentrated together both by the firms and their entrepreneurs or top executives. ${ }^{4}$

Sociological studies of elites most generally focus either on the entrepreneurs or the enterprises, as it is the case with the different surveys that Pierre Bourdieu and Monique de Saint-Martin conducted on French chief managers, single-family house builders or publishers (Bourdieu and Saint-Martin 1978, 1990; Bourdieu 1999). Yet, our hypothesis is that the new economic elite associated with the software industry cannot be dissociated from the companies they work for as it is a rather closed milieu, even if it has developed an international dimension. In this study, we focus on the top 100 national software companies, in terms of market capitalization, listed at the Mumbai National Stock Exchange (NSE) in 2012 as they constitute the main segment of the software industry specialized on projects and services.

The aims of this study are twofold and closely interlocked. The first aim is to highlight the socio-educational background of these IT entrepreneurs, or their credentials and their professional qualifications. Regarding the diversity issue of the software industry, a euphemism widely used by managers who deny the working of caste within the industry, we look at the caste origins of the entrepreneurs and ask: are the software companies really different from the "family-business" firms run by merchant groups. In order to answer this question, we turn to the next objective of this paper.

The second aim of this study deals with two related issues. Firstly, we look at the shareholding pattern of software companies. As most of these firms are first-generation, we consider the different groups of shareholders in order to determine their social origins: Indian or foreign, public or private? Secondly, we question the national character of the software companies and their access to the IT market, international or domestic, in relation with the degree of professionalization of the firms. For this purpose we use two indicators: one is the share of the global revenue drawn by geographical areas, the second is the level of certification of the firms for which we considered the Capability Maturity Model level 5 (CMM5), the highest certification recognized by NASSCOM. Thus combining shareholding pattern and sources of revenues, we reach a more appropriate understanding of the characters of the National software companies.

In order to get robust answers to these questions, I have conducted a quantitative survey using Multiple Correspondence Analysis (MCA). The purpose of this analysis is to present a sociography of software capital or, in other words, an empirically-grounded description 
of the milieu studied, which is the preliminary step before we can engage with theoretical issues.

\section{Sources, data and methods}

\section{Sources}

17 I collected the data from four main sources. The first source is the NSE that provides quantitative data regarding the market capitalization of companies and the distribution of theirs shareholders by broad categories. This information has been supplemented by the annual activity reports of the companies, which constitute our second source of information. These reports give personal details regarding members of the Board of Directors, the shareholding patterns according to the size of the shares held (information not given by the NSE), the distribution of the revenues by geographical segments (unfortunately the business segments are too heterogeneous to be codified) and, lastly, the technical certification of the firm (if any). When a firm has subsidiaries, the data coded relate to the group, that is the standalone firm and its subsidiaries. I ascertained the NASSCOM membership of the companies from the register provided by NASSCOM. Finally, I have supplemented these three main sources of information by variety of available sources (books, magazines, economic websites, like those of Dataquest, Bloomberg or Forbes) in order to complete the data collected either on the firms or regarding the biography of their managers. Although I conducted a thorough investigation of a variety of the available or easily accessible sources, the data collected always appeared unsatisfactory when compared to the time and effort invested in their collection.

\section{Data and methods}

18 The preliminary step of this research was to select the first hundred plus IT companies listed on the NSE. This selection was reached on the basis of the market capitalization of the companies over a period of ten years before the year of reference, which is the end of the 2011-2012 fiscal year. For each company I collected two sets of data: on the one hand, biographical information for one top manager, whether Chief Executive Officer (CEO), Chief Manager (CM) or Managing Director (MD), according to the structure of the Board of Directors (BoD); and, on the other hand, data related to the company itself, its economic structure and position on the IT market.

Finally the database contains 95 software companies with their executive managers, which we call statistical individuals (see the list in Appendix Table 9). For each of these individuals I constructed a set of 25 categories totaling 72 sub-categories, which characterize both the companies and their managers (see Table 2 and Table 3). The categories are classified in two sets according to their function in the MCA. First, "A" categories stand for active categories $(\mathrm{n}=16)$ subdivided into 41 active sub-categories, which create distance between individuals and contribute to the construction of clouds of points on a Euclidian space produced by MCA. Second, "S" categories stand for supplementary categories $(\mathrm{n}=9)$ subdivided into 31 sub-categories, which do not contribute to the structure of the Euclidean spaces although their coordinates, produced by MCA, allow us to locate them on these spaces. 
distinction between active and supplementary categories is always a statistical issue as well as a sociological one. Some basic methodological principles apply: the active categories should discriminate between individuals, they should not overlap, a particular set of categories should not be overstated, and finally the discrimination of the data by active categories should be clearly relevant from a sociological viewpoint. It is easily understandable to consider "Sex," "Age" and "Religion" as supplementary categories as they do not really discriminate the data: $97 \%$ of the managers are men and $95 \%$ are Hindu; the same reasoning applies for "Board status": $96 \%$ of the managers are executive managers. The categories "Graduation" and "Studies abroad" could have been defined as active categories, but "Studies abroad" would have been redundant with the category "MBA," obtained quite often from a US university, and the education variables would have weighted too heavily upon the variance of the clouds of points.

The involvement of the family in the company business is approached through the category "Family members on BoD" without distinguishing the total number of people sitting on the board. Regarding the involvement of the family in the capital, we rely only on the category "Promoters group," although some family members (children, spouses) may hold shares individually; but if we do not know the amount of shares held and the total number of family members holding shares, the category does not seem relevant to us.

Last is the category of "Caste". The coding of caste has been done mainly from a study of the surnames. Although there is uncertainty about this way of guessing caste origin, this is a means used by others scholars (Mani and Moody 2014). In order to reduce the uncertainty, I excluded State categories like Scheduled Castes, Scheduled Tribes, and Others Backward Classes, which are not pertinent for this elite milieu, and I used only broad categories that nevertheless remain quite unsatisfactory. I coded religion separately. "Caste" has been considered as a supplementary category because its coding and its sociological interpretation are too problematic to allow its use as an active category. I will come back to this issue later.

The distinction between the total number of active categories related to managers $(n=8)$ and the active categories related to companies $(n=9)$ is well balanced; all the supplementary categories are related to individuals (managers), except one: "Number of foreign subsidiaries," which intends to measure the position of the software firms on the international IT markets; yet, as this category is not straightforward I decided to include it as a supplementary instead of an active category. Information we would have liked to introduce proved difficult to obtain in a homogenous manner, even concerning some basic indicators like: number of employees, profitability, foreign countries from which the revenues are drawn, portions devoted to products and services, to research, etc. The complete set of the categories with their coding is described as follows.

241 Socio-demographic variables: Gender (S): Man, Woman. Age group (S): <45, 45-49, 5059, >60. Caste (S): Agriculture and artisan, Brahman, Merchant high-caste, Non-merchant high caste, Other, Unknown. Religion (S): Hindu, Non-Hindu.

2 Qualifications: Higher degree (A): Graduation, Post-Graduation (Master's and PhD). Type of Bachelor's degree (S): Commerce, Engineering, Science, Humanities, Law. Chartered Accountant or Company Secretary (A): Yes, No. Studies in higher institutions (A), Indian Institute of Technology (IIT), Regional or National Institute of Technology

South Asia Multidisciplinary Academic Journal, 15 | 2017 
(RIT), Indian Institute of Management (IIM): Yes, No. MBA or equivalent (A): Yes, No. Studies abroad (S): Yes, No; Honorific distinctions (A): Yes, No.

3 Position in the company: Founder of the firm (A): Yes, No. Shareholding in the company owned by the individual in percent (A): Nil, $<5 \%, 5-20 \%,>20 \%$. Board function (S): Chief Manager (CM), Managing Director (MD) or Chief Executive Officer (CEO), Managing Director or Chief Manager (MD/CM). Board status (S): Executive, NonExecutive; Family in the Board of Directors (A): Yes, No.

4 Economic structure of the firm: Year company founded: <1985, 1985-1994, >1995. Market capitalization (A): low, medium, high. Promoters share (A): Prom $<30 \%$, Prom $30-$ $50 \%$, Prom $>50 \%$. Indian Public (A): IP $<15 \%$, IP $15-40 \%$, IP $>40 \%$; Foreign Funds (A): $\mathrm{FF}<20 \%$, FF 20-40 \%, FF>40 \%; Domestic market (A): DM<20 \%, DM 20-60 \%, DM>60 \%. Certification: CMM5, Other certification, No certification. Foreign Subsidiaries (S): FS0, FS1-5; FS6-16, FS>16; NASSCOM membership: (A): Yes, No.

Multiple Correspondence Analysis: Multiple Correspondence Analysis (MCA) is a geometric data analysis technique grounded on geometric modeling that uses the mathematical theory of linear algebra. This technique, based on an inductive philosophy, is firstly a method of description of the structure of a dataset, whatever its size; it never imposes an a priori model upon the data but allows its pattern to reveals itself. MCA has been widely used within sociology in France, particularly by Pierre Bourdieu, for example in Distinction: A Social Critique of the Judgment of Taste (1979). MCA makes it possible to visualize a frequency table (statistical individuals $\mathrm{x}$ variables) by representing both individuals and categories as separate clouds of points (cloud of categories and cloud of individuals) in a Euclidian space. Although MCA differs from standard regression techniques, both can be combined; the active variables of a MCA are often considered as independent variables of regression analysis (Le Roux \& Rouanet 2010, Lebaron 2006).

To run the MCA I considered 85 companies as active individuals out of the 95 selected in the sample: for 10 of them, either the data were not complete for some categories (particularly "Domestic market") or they had some peculiarities that set them apart (for example, Tamilnadu Telecommunications Ltd is the only PSU firm, [Public Sector Undertaking] whose capital is $100 \%$ held by Public funds). These 10 firms have been entered as supplementary individuals and thus they do not contribute to the clouds of points. But using their coordinates given by the MCA, these firms can be located within the cloud of individuals and also affected to a partition of the cloud.

The first step of the MCA is the construction of Euclidian spaces defined by different couples of axes on which are plotted the cloud of categories and the cloud of individuals. Then in a second step, I conducted an Ascending Hierarchical Classification (AHC) on the principal components of the factorial analysis. The aim of the AHC is to get a partition of the cloud of the 95 companies into a couple of clusters which would correspond to the profile of companies and managers revealed by the cloud of categories. The hierarchical tree produced by the MCA suggested a classification into 3 clusters that provide a map of the social space of the software companies. 


\section{Cartography of Indian software capital: credentials, market and shareholding}

Before we describe the space of the software companies, we need to explain how the space is structured. Table 1 gives the contributions ${ }^{6}$ of the first 4 axes to the variance of the clouds of points, which contribute to the structuration of the space of software companies. The contribution of axis 1 is $31.61 \%$, in other words, we say that axis 1 , which has the higher contribution, "explains" $31.61 \%$ of the clouds of points. We notice that the contribution of axis 2 , which is $30.29 \%$, has a value almost equal to the contribution of axis 1 . Cumulated together, axes 1 and 2 explain $62 \%$ of the clouds of points. The contribution of axis $3,17.05 \%$, is about half the contributions to the first 2 axes, while the contribution of axis $4,8.43 \%$, is half that of axis 3 . The cumulated value of the first 3 axes explain almost $80 \%$ of the clouds of points, therefore there is not much gain to extending the interpretation beyond axe 3 .

Table 1: Contributions of the 4 first axes to clouds of points (\%)

\begin{tabular}{|l|l|l|}
\hline Axes & Contr. \% & Cumul. contr. \% \\
\hline 1 & 31.61 & 31.61 \\
\hline 2 & 30.29 & 61.90 \\
\hline 3 & 17.05 & 78.95 \\
\hline 4 & 8.43 & 87.38 \\
\hline
\end{tabular}

\section{Credentials and positions on the IT market}

32 We shall now analyze the main socio-economic categories that structure the different axes (Tables 2 and 3, Graphs 1 and 2). The IT top managers who are predominantly men (there are only 3 women $^{7}$ in the panel) and $\operatorname{Hindu}^{8}(94 \%)$, constitute a highly educated group; all of them have graduated at least. ${ }^{9}$ If we consider the field of graduation (Table 3), $54 \%$ of the top managers graduated in engineering and $15 \%$ in science, quite often in engineering science (like information technology), which means that collectively these elite managers hold the same kind of educational capital in its engineering component and, therefore, they share the same technical culture. Yet beneath these common features, our analysis revealed a main opposition along axis 1 according both to the specific credentials of the top managers and to the strength of the companies they work for, which determines their position on the IT market.

Table 2: Coordinates and contributions of active categories (axes 1, 2, 3)

\begin{tabular}{|c|c|c|c|c|c|}
\hline Categories & $\mathrm{Nb}$ & $\%$ & $\begin{array}{l}\text { Axis } 1(31,61 \% \\
\text { ) }\end{array}$ & $\begin{array}{l}\text { Axis } 2(30,29 \% \\
)\end{array}$ & $\begin{array}{l}\text { Axis } 3(17,05 \% \\
)\end{array}$ \\
\hline
\end{tabular}




\begin{tabular}{|c|c|c|c|c|c|c|c|c|}
\hline & & & coord. & contr. & coord. & contr. & coord. & contr. \\
\hline \multicolumn{9}{|l|}{ Founder } \\
\hline Founder & 60 & 63 & $-0,16$ & 0,64 & $-0,18$ & 0,82 & 0,28 & 2,44 \\
\hline notFounder & 35 & 37 & 0,29 & 1,18 & 0,32 & 1,50 & $-0,52$ & 4,47 \\
\hline Total & 95 & 100 & & 1,82 & & 2,32 & & 6,91 \\
\hline \multicolumn{9}{|l|}{ Higher degree } \\
\hline Graduation & 36 & 38 & 0,71 & 7,60 & 0,67 & 6,94 & 0,22 & 0,88 \\
\hline Master's \& PhD & 59 & 62 & $-0,43$ & 4,59 & $-0,41$ & 4,19 & $-0,13$ & 0,54 \\
\hline Total & 95 & 100 & & 12,19 & & 11,13 & & 1,42 \\
\hline \multicolumn{9}{|l|}{ MBA, PGDM } \\
\hline MBA, PGDM & 41 & 43 & $-0,54$ & 4,83 & $-0,61$ & 6,36 & $-0,18$ & 0,66 \\
\hline noMBA, PGDM & 54 & 57 & 0,39 & 3,55 & 0,45 & 4,67 & 0,13 & 0,49 \\
\hline Total & 95 & 100 & & 8,38 & & 11,03 & & 1,15 \\
\hline \multicolumn{9}{|l|}{ Chartered Act. } \\
\hline ChartAct & 14 & 15 & 0,59 & 2,12 & 0,58 & 2,08 & $-0,98$ & 7,04 \\
\hline noChartAct & 81 & 85 & $-0,11$ & 0,38 & $-0,11$ & 0,37 & 0,18 & 1,27 \\
\hline Total & 95 & 100 & & 2,50 & & 2,45 & & 8,31 \\
\hline \multicolumn{9}{|l|}{ IIT, RIT, IIM } \\
\hline IIT, RIT, IIM & 26 & 27 & $-0,86$ & 8,32 & $-0,09$ & 0,10 & 0,08 & 0,09 \\
\hline noIIT, IIM & 69 & 73 & 0,34 & 3,27 & 0,04 & 0,04 & $-0,03$ & 0,03 \\
\hline Total & 95 & 100 & & 11,59 & & 0,14 & & 0,12 \\
\hline \multicolumn{9}{|l|}{ Shareholding \% } \\
\hline $\mathrm{SH} 0 \mathrm{pc}$ & 28 & 30 & 0,01 & 0,10 & 0,41 & 1,92 & 0,31 & 1,28 \\
\hline $\mathrm{SH}<5 \mathrm{pc}$ & 25 & 26 & $-0,22$ & 0,53 & 0,48 & 2,54 & $-0,76$ & 7,34 \\
\hline SH 5-20 pc & 23 & 24 & 0,24 & 0,57 & $-0,12$ & 0,15 & 0,01 & 0,01 \\
\hline $\mathrm{SH}>20 \mathrm{pc}$ & 19 & 20 & $-0,13$ & 0,14 & $-1,08$ & 9,45 & 0,57 & 3,06 \\
\hline Total & 95 & 100 & & 1,34 & & 14,06 & & 11,69 \\
\hline
\end{tabular}




\begin{tabular}{|c|c|c|c|c|c|c|c|c|}
\hline Distinctions & & & & & & & & \\
\hline Distinction & 30 & 32 & $-0,74$ & 7,44 & 0,32 & 1,39 & 0,38 & 2,39 \\
\hline noDistinction & 65 & 68 & 0,38 & 3,85 & $-0,16$ & 0,72 & $-0,20$ & 1,24 \\
\hline Total & 95 & 100 & & 11,29 & & 2,11 & & 3,63 \\
\hline \multicolumn{9}{|l|}{ Family BoD } \\
\hline FamilyBoD & 35 & 37 & 0,36 & 1,91 & $-0,21$ & 0,63 & 0,58 & 5,76 \\
\hline noFamilyBoD & 60 & 63 & $-0,21$ & 1,10 & 0,12 & 0,36 & $-0,33$ & 3,31 \\
\hline Total & 95 & 100 & & 3,01 & & 0,99 & & 9,07 \\
\hline \multicolumn{9}{|l|}{ Year founded } \\
\hline$<1985$ & 16 & 17 & $-0,44$ & 1,47 & 0,29 & 0,63 & 0,64 & 3,71 \\
\hline $1985-1994$ & 48 & 50 & 0,14 & 0,39 & 0,23 & 1,04 & $-0,32$ & 2,33 \\
\hline > 1995 & 31 & 33 & 0,05 & 0,03 & $-0,48$ & 3,18 & 0,09 & 0,13 \\
\hline Total & 95 & 100 & & 1,89 & & 4,85 & & 6,17 \\
\hline \multicolumn{9}{|l|}{ Market capit. } \\
\hline High mkt cap. & 33 & 34 & $-0,67$ & 6,77 & 0,56 & 4,85 & 0,04 & 0,04 \\
\hline Mid mkt cap. & 31 & 33 & 0,66 & 5,59 & 0,22 & 0,60 & 0,04 & 0,03 \\
\hline Low mkt cap. & 31 & 33 & 0,16 & 0,28 & $-0,97$ & 11,14 & $-0,11$ & 0,15 \\
\hline Total & 95 & 100 & & 12,64 & & 16,59 & & 0,22 \\
\hline \multicolumn{9}{|c|}{ Promoters share \% } \\
\hline Promo $<30 \mathrm{pc}$ & 26 & 27 & $-0,11$ & 0,12 & 0,07 & 0,06 & $-1,14$ & 15,90 \\
\hline Promo $30-50 \mathrm{pc}$ & 30 & 32 & $-0,32$ & 1,23 & $-0,51$ & 3,21 & 0,02 & 0,01 \\
\hline Promo $>50 \mathrm{pc}$ & 39 & 41 & 0,29 & 1,44 & 0,31 & 1,73 & 0,66 & 9,02 \\
\hline Total & 95 & 100 & & 2,79 & & 5,00 & & 24,93 \\
\hline \multicolumn{9}{|l|}{ Indian Public } \\
\hline $\mathrm{IP}<15 \mathrm{pc}$ & 26 & 27 & $-0,27$ & 0,88 & 0,93 & 10,37 & 0,21 & 0,64 \\
\hline IP $15-40 \mathrm{pc}$ & 46 & 48 & 0,04 & 0,03 & $-0,28$ & 1,58 & 0,36 & 3,02 \\
\hline $\mathrm{IP}>40 \mathrm{pc}$ & 23 & 25 & 0,29 & 0,71 & $-0,64$ & 3,52 & $-1,14$ & 12,95 \\
\hline
\end{tabular}




\begin{tabular}{|c|c|c|c|c|c|c|c|c|}
\hline Total & 95 & 100 & & 1,62 & & 15,47 & & 16,61 \\
\hline \multicolumn{9}{|c|}{ Foreign Funds } \\
\hline $\mathrm{FF}<20 \mathrm{pc}$ & 42 & 44 & 0,37 & 2,31 & $-0,32$ & 1,77 & 0,16 & 0,50 \\
\hline FF $20-40 \mathrm{pc}$ & 33 & 35 & $-0,39$ & 2,24 & 0,08 & 0,10 & 0,23 & 0,94 \\
\hline $\mathrm{FF}>40 \mathrm{pc}$ & 20 & 21 & $-0,06$ & 0,04 & 0,50 & 2,14 & $-0,72$ & 5,16 \\
\hline Total & 95 & 100 & & 4,59 & & 4,01 & & 6,60 \\
\hline \multicolumn{9}{|c|}{ Domestic market } \\
\hline $\mathrm{DM}<20 \mathrm{pc}$ & 34 & 36 & $-0,49$ & 3,90 & 0,12 & 0,22 & $-0,17$ & 0,53 \\
\hline DM $20-60 \mathrm{pc}$ & 22 & 23 & $-0,06$ & 0,04 & $-0,29$ & 0,85 & $-0,12$ & 0,18 \\
\hline $\mathrm{DM}>60 \mathrm{pc}$ & 30 & 32 & 0,60 & 5,16 & 0,13 & 0,07 & 0,35 & 1,29 \\
\hline na & 9 & 9 & & $\mathrm{nr}$ & & $\mathrm{nr}$ & & $\mathrm{nr}$ \\
\hline Total & 95 & 100 & & 9,10 & & 1,14 & & 2,00 \\
\hline \multicolumn{9}{|l|}{ Certification } \\
\hline CMM5Cert. & 12 & 13 & $-1,40$ & 11,03 & 0,70 & 2,82 & $-0,11$ & 0,08 \\
\hline othersCert. & 37 & 39 & 0,21 & 0,72 & $-0,01$ & 0,01 & 0,07 & 0,09 \\
\hline noCert. & 46 & 48 & 0,25 & 1,11 & $-0,21$ & 0,82 & $-0,03$ & 0,02 \\
\hline Total & 95 & 100 & & 12,86 & & 3,65 & & 0,19 \\
\hline \multicolumn{9}{|l|}{ Nasscom } \\
\hline Nasscom & 59 & 62 & $-0,18$ & 0,81 & 0,22 & 1,74 & 0,10 & 0,34 \\
\hline noNasscom & 36 & 38 & 0,34 & 1,57 & $-0,49$ & 3,35 & $-0,20$ & 0,66 \\
\hline Total & 95 & 100 & & 2,38 & & 5,09 & & 1,00 \\
\hline
\end{tabular}

READINg. We consider the $2^{\text {nd }}$ category "Higher Degree." The total contributions of this category to axis $1(12.19 \%)$ and axis $2(11.12 \%)$ are almost equal and high, far above the mean contribution $(2.44 \%)$ of the categories. The respective contributions to axis 1 are $7.60 \%$ for "Graduation" and $4.59 \%$ for "Master's and PhD." The coordinates of "Graduation" are positive on axis 1 and axis 2; this is the reason why this category is located on the upper-right quadrant. Conversely, the coordinates of "Master's and PhD" are negative on both axis 1 and axis 2, therefore the category is located on the lower-left quadrant, at the opposite side of "Graduation" (na = not available, $\mathrm{nr}=$ non relevant).

Table 3: Coordinates of supplementary categories (axes 1, 2, 3)

\begin{tabular}{|l|l|l|l|l|l|}
\hline Categories & Nb & $\%$ & Axis 1 (31,61 \%) & Axis 2 (30,29\%) & Axis 3 (17,05\%) \\
\hline
\end{tabular}




\begin{tabular}{|c|c|c|c|c|c|}
\hline Gender & & & & & \\
\hline Man & 92 & 97 & $-0,02$ & 0,00 & $-0,01$ \\
\hline Woman & 3 & 3 & 0,88 & $-0,18$ & 0,61 \\
\hline Total & 95 & 100 & & & \\
\hline \multicolumn{6}{|l|}{ Age groups } \\
\hline$<45$ & 11 & 12 & 0,22 & $-0,21$ & 0,37 \\
\hline $45-49$ & 27 & 28 & 0,15 & $-0,16$ & $-0,12$ \\
\hline $50-59$ & 33 & 35 & $-0,06$ & 0,03 & $-0,10$ \\
\hline$>60$ & 20 & 21 & $-0,25$ & 0,27 & 0,14 \\
\hline na & 4 & 4 & & & \\
\hline Total & 95 & 100 & & & \\
\hline \multicolumn{6}{|l|}{ Religion } \\
\hline Hindu & 89 & 94 & $-0,02$ & $-0,03$ & 0,03 \\
\hline Others & 6 & 6 & 0,21 & 0,42 & $-0,40$ \\
\hline Total & 95 & 100 & & & \\
\hline \multicolumn{6}{|l|}{ Caste } \\
\hline AgricArtisan & 22 & 23 & $-0,27$ & $-0,43$ & $-0,18$ \\
\hline Brahman & 27 & 28 & $-0,11$ & 0,32 & $-0,38$ \\
\hline Merchant high castes & 15 & 16 & 0,32 & 0,12 & 0,10 \\
\hline Non-Merchant high castes & 22 & 23 & 0,15 & $-0,14$ & 0,43 \\
\hline Other & 5 & 6 & 0,13 & 0,64 & $-0,02$ \\
\hline Unknown & 4 & 4 & & & \\
\hline Total & 95 & 100 & & & \\
\hline \multicolumn{6}{|l|}{ Graduation } \\
\hline Commerce & 23 & 24 & 0,29 & 0,12 & $-0,53$ \\
\hline Engineering & 51 & 54 & $-0,15$ & $-0,05$ & 0,25 \\
\hline Science & 14 & 15 & $-0,31$ & 0,01 & $-0,08$ \\
\hline
\end{tabular}




\begin{tabular}{|c|c|c|c|c|c|}
\hline Humanities & 3 & 3 & 0,84 & $-0,64$ & 0,52 \\
\hline Law & 4 & 4 & 0,77 & 0,22 & 0,01 \\
\hline Total & 95 & 100 & & & \\
\hline \multicolumn{6}{|l|}{ Studies abroad } \\
\hline Aboad & 29 & 30 & $-0,22$ & $-0,26$ & 0,07 \\
\hline NotAbroad & 66 & 70 & 0,11 & 0,13 & $-0,03$ \\
\hline Total & 95 & 100 & & & \\
\hline \multicolumn{6}{|l|}{ Board function } \\
\hline $\mathrm{CM}$ & 10 & 11 & 0,00 & $-0,05$ & 0,21 \\
\hline $\mathrm{MD} / \mathrm{CEO}$ & 37 & 39 & 0,18 & 0,22 & $-0,21$ \\
\hline $\mathrm{MD} / \mathrm{CM}$ & 48 & 50 & $-0,13$ & $-0,13$ & 0,10 \\
\hline Total & 95 & 100 & & & \\
\hline \multicolumn{6}{|l|}{ Board status } \\
\hline Executive & 92 & 97 & 0,00 & 0,02 & 0,01 \\
\hline Non-executive & 3 & 3 & $-0,10$ & $-0,57$ & $-0,27$ \\
\hline Total & 95 & 100 & & & \\
\hline \multicolumn{6}{|c|}{ Foreign subsidiaries } \\
\hline FSubsd 0 & 13 & 14 & 0,84 & 0,01 & 0,12 \\
\hline FSubsd 1-5 & 40 & 42 & 0,25 & $-0,36$ & $-0,04$ \\
\hline FSubsd 6-14 & 30 & 32 & $-0,35$ & 0,04 & 0,02 \\
\hline FSubsd $>15$ & 12 & 12 & $-0,55$ & 0,91 & $-0,03$ \\
\hline Total & 95 & 100 & & & \\
\hline
\end{tabular}


Graph 1: The space of Indian software capital. The cloud of active and supplementary categories (Axes 1-2)

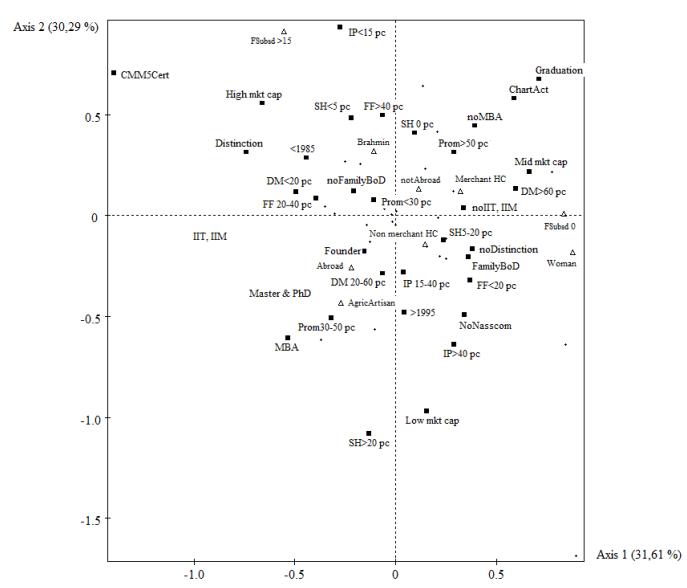

Graph 2 : Social Space of Indian Software Capital (simplified)

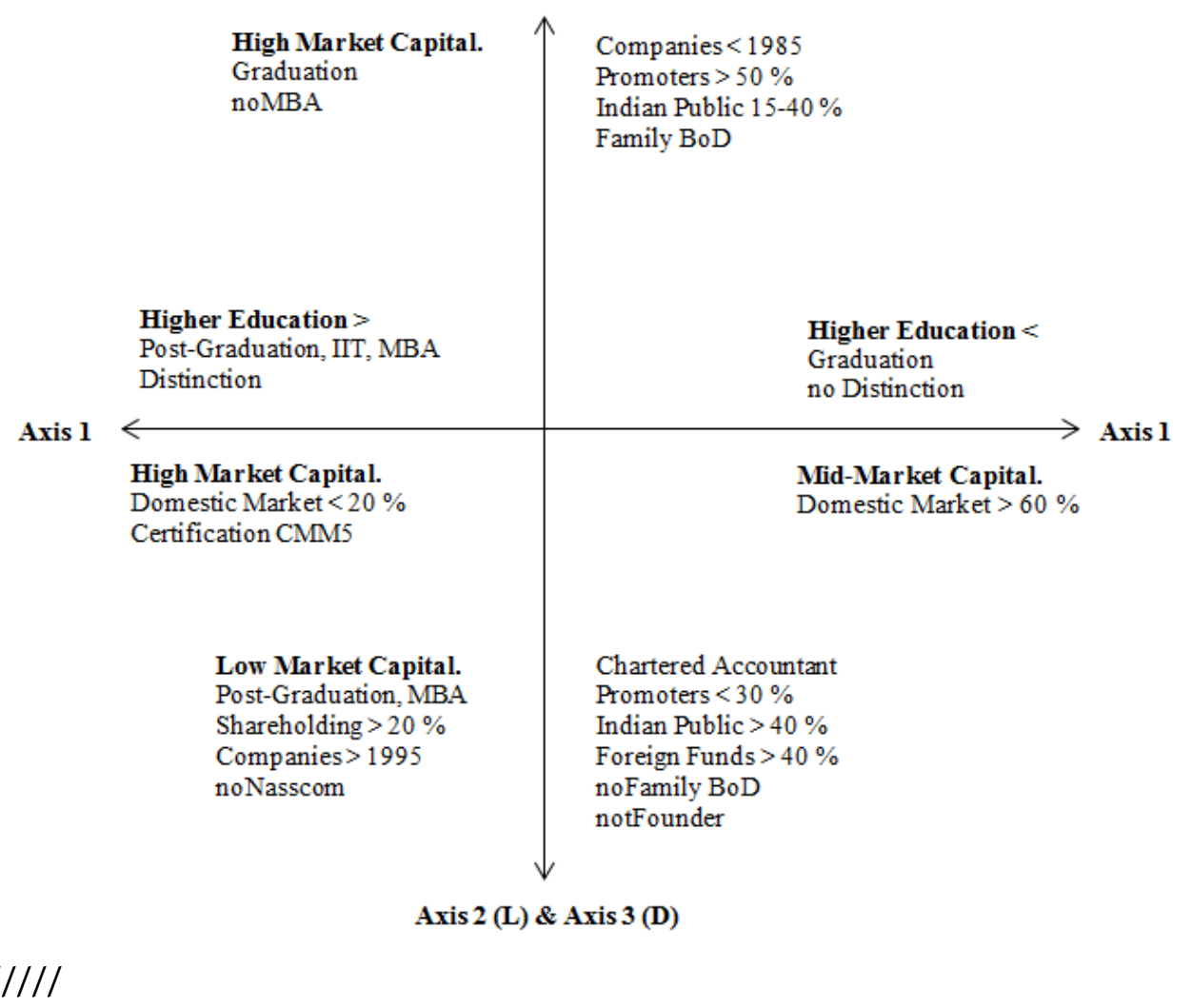

On the one hand (on the left of the diagram), we find the managers who have the highest level of education: they hold a Master's or a $\mathrm{PhD}(62 \%)$, plus an MBA for almost half of them (43\%), obtained quite often abroad ( $30 \%)$ in a US university, and for less than a third (27\%) they studied at a premium higher institution, an IIT or an NIT for their engineering graduation, or an IIM for a Post-Graduate Diploma in Management. These highly-educated top managers hold positions as CEO or CM in big software companies that are characterized by a high market capitalization and a high standard of professionalization evidenced by CMM5 certification. ${ }^{10}$ These Indian multinational 
companies draw the main part of their revenue from the international IT market: less than $20 \%$ only of their total revenue is realized on the domestic market. Finally, a third of the top managers ( $32 \%$ ), mainly located on left of axis 1 , are honored by awards (honorary $\mathrm{PhD}$, professional distinctions or national awards) for their personal achievements in the IT sector.

One significant example is Krishnakumar Natarajan, a co-founder of MindTree in 1999, one of the first venture capitalist-backed IT companies, now a mid-size services firm where he was the CEO and the CM in 2012. K. Natarajan was born in 1958 in a Tamil Brahman family whose father was a civil servant, a doctor in the Indian Railway Medical Services, and his mother a house-wife. In 1979, he graduated in Mechanical from the College of Engineering of Guindy in Chennai; as he could not go abroad to pursue PostGraduate work as he wished, in 1981 he completed his MBA from the well-known XLRIXavier School of Management of Jamshedpur. Then from 1982 to 1999 he worked for 17 years with Wipro where he was the CEO of the Electronic Commerce Division. In 2012, K. Natarajan served as Vice Chairman of the Executive Council of NASSCOM. He has been honored by several awards from the IT industry, like the Bloomberg UTV's award as CEO of the year 2010 in the Emerging company category.

On the other hand, at the opposite side of axis 1 (on the right of the diagram), the managers are characterized by a lower level of higher education: many of them are graduates but not necessarily from an IIT or an NIT and they do not hold an MBA. The software companies they work for have a mid-market capitalization and their IT activities are more oriented towards India as $32 \%$ of the companies draw more than $30 \%$ of their revenues from the domestic market.

Omnitech Infosolution, a company co-founded in 1990 by Atul Maganlal Hemani, is one example. Born in 1962, Atul Hemani holds a Bachelor's of Engineering-Electrical from the University of Bombay. Before founding his own company, he worked for two years with HCL. Omnitech helps corporates to develop and manage IT applications and infrastructure, particularly in the banking and financial sector, and in 2012 it realized $75 \%$ of its revenue on the domestic market.

\section{Positions on the IT market and shareholding pattern}

The second factor of the MCA, or axis 2, differentiates the companies once more according to the credentials of the top managers and the economic size of the companies in terms of market capitalization (Graph 3). It opposes, on the top of the diagram, the managers who are graduates but do not hold an MBA, and the companies that have a high market capitalization and, at the bottom of the diagram, companies with low market capitalization and top managers whose credentials (Post Graduation and MBA) are high. Yet in order to understand the structure of software capital, we need to consider together the second and the third factor as axis 3 differentiates the companies mainly according to the shareholding pattern.

Table 4: Main shareholders of Indian software capital in \% of the total number of equity- shares holders $(n=95)$

Types of shareholders $\%$ 


\begin{tabular}{|l|l|}
\hline Indian Promoters & 40,7 \\
\hline Indian Public & 24,2 \\
\hline Foreign funds & 26,5 \\
\hline Others & 8,6 \\
\hline Total & 100,0 \\
\hline
\end{tabular}

In order to estimate the weight of national capital on the shareholding pattern, we have divided shareholders into 4 main categories (Table 4). The group of promoters, who are predominantly Indian, ${ }^{11}$ holds almost $41 \%$ of equity-shares while the second half of software capital is divided almost equally between individual holders (Indian Public) for $24.2 \%$ and Foreign funds for $26.5 \%$ (there is not a single firm without Foreign funds); the last category, which holds less than $9 \%$ of the equity-shares, is made of small Indian Institutional holders (Central and State Governments, Mutual Funds, Banks). In other words, almost $70 \%$ of software capital is Indian in origin, or conversely about $30 \%$ of the capital is controlled by foreign funds.

This study confirms what we have learnt from the literature review. IT companies are characterized by concentration of the shareholding in the hands of the family members who control the firm through the mechanisms of the promoters group. ${ }^{12}$ Yet, this distribution of the number of equity-shares among the main groups of shareholders does not say much about the value of the equity-shares they hold. Unfortunately, the data we need to measure this value is not available in the Annual Activity Reports. In order to approach this issue we present the distribution of the shareholding pattern according to the size of the equity-shares (Table 5).

Table 5: Shareholding pattern of Indian software companies according to the size and value of the equity-shares in \% $(n=95)$

\begin{tabular}{|l|l|l|}
\hline Nb of Shares & Holders (\%) & Value (\%) \\
\hline$<5,000$ & 95.7 & 7.5 \\
\hline $5,000-10,000$ & 2.0 & 0.7 \\
\hline$>10,000$ & 2.3 & 91.6 \\
\hline Total & 100.0 & 100.0 \\
\hline
\end{tabular}

If we compare the number of shares held and their value in terms of capital, ${ }^{13}$ the distribution of the shareholding presents a clearly chiasmic structure: the mass of small holders represents almost $96 \%$ of the total shareholders but they control less than $8 \%$ of the capital while about $2 \%$ of the shareholders hold almost $92 \%$ of the capital. Clearly there are two levels of concentration of the equity-shares, firstly regarding the main groups of shareholders and, secondly, in terms of size and value of the shareholding, a fact not mentioned by the authors in the management literature. The individual small 
holders (Indian Public), who hold almost a quarter of the number of shares, do not control much in terms of value of the equity-shares; yet their weight on the shareholding pattern of the different companies gives us a hint of the openness of the software enterprises towards the Indian Public group on the stock-market.

The third axis of the factorial analysis, combined with the second one, differentiates between two categories of firms where the first makes no distinction. On the one hand (at the top of the diagram), are located the oldest IT companies, founded before 1985, whose promoters group hold above $50 \%$ of the equity-shares while the share of the individual holders is medium, $15-40 \%$.

The company that best exemplifies this position would be Wipro, located at the top of axis 2 , slightly on the right of the diagram. Although Wipro began as a vegetable-oil manufacturer in 1945, the company entered the IT industry in the early 1980s through the manufacture and sale of mini-computers. Ten years later, Wipro had developed its software expertise, particularly in offshore services, and it had transformed itself into a major IT firm. The man who was behind the technological turn of the company is Azim Premji. Born in 1945, Azim Premji was studying electrical engineering at Stanford University in the US, when the sudden death of this father in 1966 compelled him to come back to India. He then succeeded his father at the head of Wipro and became its CEO from 1968 to 2011. In 2012, he became the Chairman of the Board of Directors and T. K. Kurien served as the CEO, IT Business and executive director, and also as member of the Wipro Executive Corporate Council. Both top managers belong to non-Hindu denominations: Azim Premji is an Isma'ili Shia Muslim from Western India while T. K. Kurien is a Syrian Christian from Kerala. Born in 1960, Kurien who has been educated at Hyderabad is not an engineer but a Chartered Accountant; he joined Wipro in 2000 and worked over 10 years for Wipro GE Healthcare (a subsidiary of General Electric). Wipro shareholding is controlled by the Promoters group that holds $78 \%$ of the total equity-shares; Foreign funds are the second group, with $11 \%$ of the capital, while the equity-shares of individual residents, Indian Public, is at a low $7 \%$. Wipro draw $21 \%$ of its revenue from the domestic market, but the company has never completely stopped its activities as a vegetable-oil manufacturer. In 2011, Azim Premji was awarded Padma Vibhushan, the second highest civilian award, by the Government of India for his outstanding achievements in the IT sector.

On the other hand (at the bottom of the diagram) we have a concentration of top managers with a high level of education (Post-Graduation and MBA), like those situated on the left of axis 1, combined with comparatively young IT companies, founded after 1995, and characterized by low market capitalization, lesser control by the Promoters groups (less than $30 \%$ ), and a higher share of Indian Public funds. I come back to the managers and companies located in this lower part of the space in the following section.

\section{The 3 clusters of Indian software capital}

So far, I have described the three main factors, or axes, that structure the space of Indian software capital according to the different categories designed for the MCA. I now synthetize this description in focusing on the 3 main clusters that are the outcome of the hierarchical classification. These 3 clusters and their barycenters (weighted average of points) are represented on Graph 3 while Table 6 details the main categories that characterize each cluster. These 3 classes of firms have unequal economic strength on the 
software market, which is in part the result of the history of the software industry in India.

Graph 3: The 3 clusters of Indian software capital (Axes 1-2)

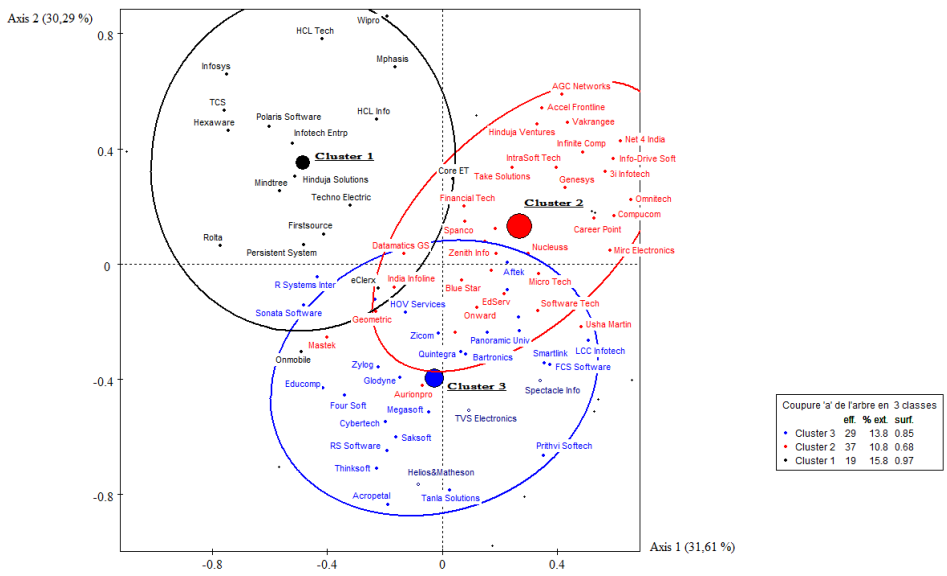

Table 6: The 3 clusters of software capital according to the main categories

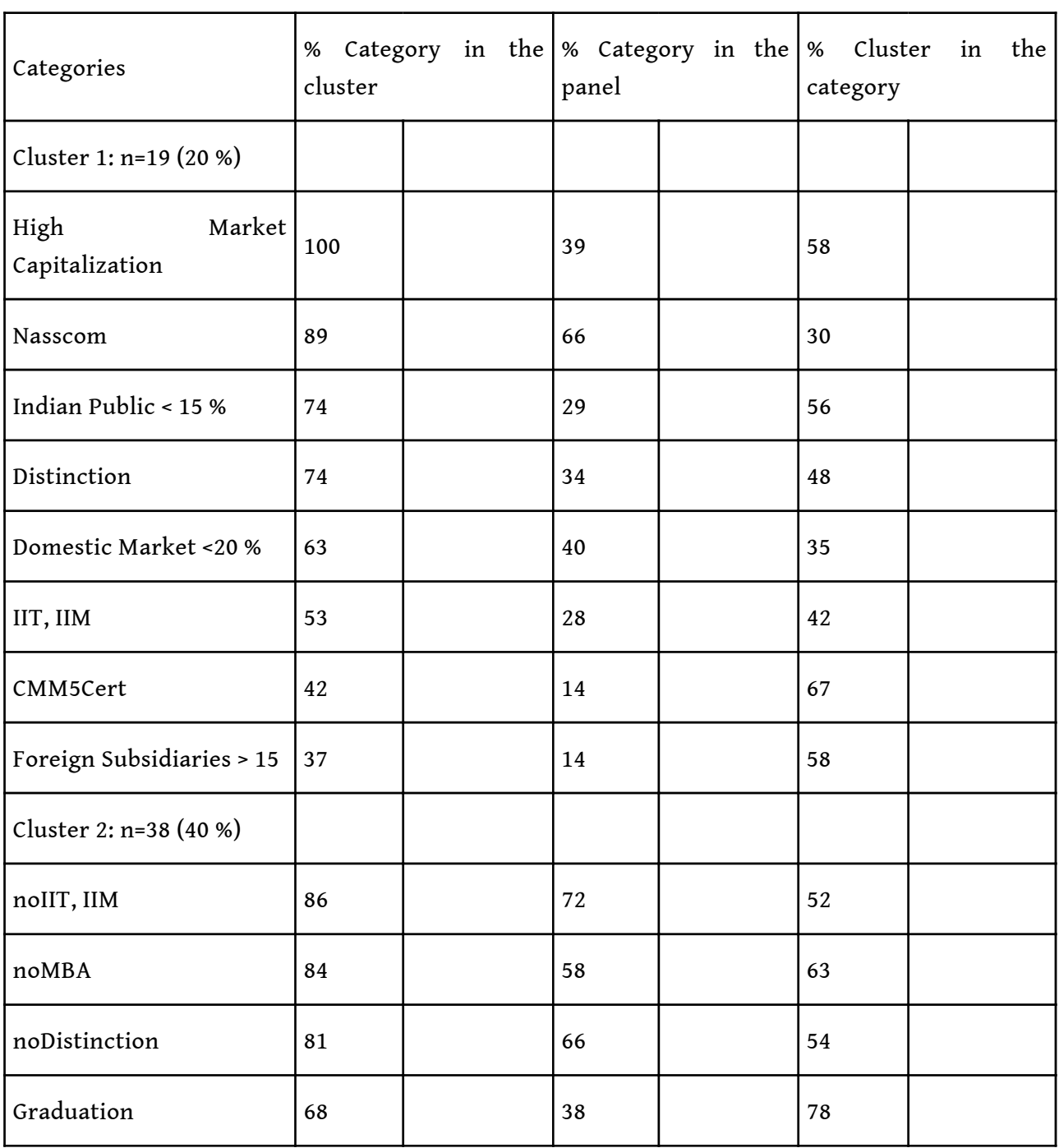




\begin{tabular}{|c|c|c|c|}
\hline Indian Public $15-40 \%$ & 68 & 49 & 60 \\
\hline NoCertification & 65 & 45 & 63 \\
\hline $\begin{array}{l}\text { Mid-Market } \\
\text { Capitalization }\end{array}$ & 57 & 32 & 78 \\
\hline Domestic Market $>60 \%$ & 51 & 34 & 66 \\
\hline Shareholding 5-20\% & 43 & 25 & 76 \\
\hline Cluster 3: $\mathrm{n}=38(40 \%)$ & & & \\
\hline Post-Graduation & 93 & 62 & 51 \\
\hline $\begin{array}{ll}\text { Low } & \text { Market } \\
\text { Capitalization } & \end{array}$ & 69 & 29 & 80 \\
\hline MBA & 69 & 42 & 56 \\
\hline Foreign Funds $<20 \%$ & 62 & 42 & 50 \\
\hline noNasscom & 59 & 34 & 59 \\
\hline Foreign Subsidiaries 1-15 & 59 & 40 & 50 \\
\hline Indian Public $>40 \%$ & 55 & 21 & 89 \\
\hline Shareholding $>20 \%$ & 41 & 20 & 71 \\
\hline AgricArtisan & 34 & 19 & 63 \\
\hline
\end{tabular}

READINg CLUSTER 1. We consider the category "High Market Capitalization," $1^{\text {st }}$ column, $2^{\text {nd }}$ line. All the 19 companies in cluster 1, that is $100 \%$, are characterized by "High Market Capitalization" ( ${ }^{\text {nd }}$ column) while this category accounts for $39 \%$ only in the whole population studied ( $3^{\text {rd }}$ column). Moreover, the companies characterized by "High Market Capitalization" in cluster 1 represent $58 \%$ of all the "High Market Capitalization" companies in the panel studied (4th $c o l u m n)$.

\section{The Indian Multinational software companies}

The first cluster groups together 19 companies (20\% of the 95 firms studied) which are located on the upper-left quadrant of the diagram (the barycenter of the cluster is almost at the center of the quadrant). All 19 companies have a high market capitalization and almost all of them are members of NASSCOM. This is clearly the class of the Indian Multinational software companies where we find: TCS, Infosys, Wipro, HCL Technologies, Mphasis, Hexaware, MindTree, or Core Education, an IT education service company.

The high market capitalization has to be related to the age of these firms, which have been founded before 1985. These companies drew less than $20 \%$ of their revenue from the domestic market as they worked mainly for the international IT market through their subsidiaries (most of these big firms managed more than 15 foreign subsidiaries in 2012). 
The high number of CMM5 certification is an indicator of the professionalization of these companies: $67 \%$ of the firms with this certificate belong to cluster 1 .

Table 7: Market capitalization of the 6 first software companies compared to the total market capitalization of the companies studied in $\%(n=95)$

\begin{tabular}{|l|l|l|}
\hline Company & \% market cap. & Cumul. \% \\
\hline TCS & 38.9 & 38.9 \\
\hline Infosys & 28.0 & 66.9 \\
\hline Wipro & 18.4 & 85.3 \\
\hline HCL Technologies & 5.7 & 91.0 \\
\hline Mphasis & 1.4 & 92.4 \\
\hline Hexaware Technologies & 0.6 & 93.0 \\
\hline
\end{tabular}

The most remarkable character of these software companies is there unequal economic strength on the IT market (Table 7). In fact 3 firms only-TCS, Infosys and Wiprotogether produced $85.3 \%$ of the total market capitalization of the 95 firms studied; there is a sharp decrease in the share of market capitalization for the next firms: HCL Technologies 5.7\%, Mphasis $1.4 \%$ and the sixth one, Hexaware Technologies represents only $0.6 \%$ of the total market capitalization of the panel. The ranking of these firms according to their market capitalization is congruent with the strength of their workforce in 2012: TCS ranks first with 240,000 employees, then Infosys 150,000, Wipro 140,000, HCL Technologies 85,000; below these biggest brands are companies with a workforce of 30,000 people or less like Mphasis or FirstSource. In other words, out of the 95 companies surveyed, Indian national software capital is concentrated in the hands of three big companies, and a sixth of the first companies accounts for $93 \%$ of market capitalization. Not only is there a double level of concentration of software capital in terms of shareholding pattern, but furthermore a handful of software companies concentrate the market value of the software industry and compete in order to maintain or expand it.

If we consider the top managers associated with these Indian multinational companies, about half of them have been educated in a premium institution (IIT, NIT or IIM), while less than a third have in the panel as a whole: 14 out of 19 hold a Master's Degree and 10 an MBA. Thirty years ago, an MBA was not necessarily a prerequisite to succeed in the IT industry. The founders or executive managers of TCS, Infosys and Mphasis have a Master's Degree in Engineering but no MBA. Yet, these billionaire managers who make the regular headlines of the American magazine Forbes, became IT magnates in a generation, and they are the most distinguished $(74 \%)$ of our panel in terms of honorific distinctions.

Regarding the individual equity-shares of these top managers, very few hold more than 5 $\%$ of the shareholding (although we should consider the shares held by their spouses and children, information not always disclosed). In fact, the top managers control the shareholding through the Promoters group whose share is quite high even for the 
Multinational companies: 78 \% for Wipro, $74 \%$ for TCS, $51 \%$ for HCL, but $16 \%$ only for Infosys which has the highest Indian Public share, $13 \%$, combined with the highest portion of Foreign funds, $54 \%$.

50 Among the 4 giants of the IT industry, HCL and Infosys deserve particular attention. While TCS is an offshoot of the Tata conglomerate and Wipro a reinvented vegetable-oil manufacturer, HCL and Infosys epitomize the success of the IT companies that emerged from the 1970s onward. $\mathrm{HCL}^{14}$ was founded in Delhi in 1976 by six engineers who came out of the IT division of a typical Indian merchant firm, DCM (Delhi Cloth Mills). The man who led the move, Shiv Nadar, was born in 1945 in a Tamil Nadar ${ }^{15}$ family whose father was a judge. In 1967, Shiv Nadar graduated in Electrical and Electronics engineering from the PSG College of engineering of Coimbatore, in the far south of the state of Tamil Nadu. Then the 22 year old engineer who had never visited even Madras (now Chennai), move to Poona and Delhi where he joined the new IT division that DCM was developing as software engineer, before starting his own venture some years later. At the end of the 1970s, Nadar made and sold micro-computers and digital calculators, as did Azim Premji with Wipro. But the liberalization of the Indian economy in the 1980 s caused difficulties for the hardware sector as it could not compete with the imported computers, which were far cheaper than the Indian brands. Then, the nascent software industry reoriented itself towards IT services, a move initiated earlier by TCS, which was founded in 1968. Today Shiv Nadar has not only extended the area of the company's IT services with the founding in 1986 of its main subsidiary, HCL Infosystems, he has also ventured into the area of higher education by opening first the SSN College of Engineering at Chennai and second, the Nadar University at Noida (Uttar Pradesh); his wife, Kiran, is an Indian art collector, founder of the Kiran Nadar Museum of Art at Delhi, while the museum has also a gallery within the premises of HCL headquarters at Noida.

51 Like HCL, Infosys was founded in 1981 at Poona by a group of 7 engineers led by N. R. Narayana Murthy, who were both working for Patni Computer Systems, an IT company then run by a Marwari Jain business family. Among the seven founders, 6 were South Indian from Karnataka, Tamil Nadu or Kerala, and 5 were Brahmans, while the last one was a Punjabi. The leading founder, Narayana Murthy, was born in 1946 in a Kannada Brahman family from Mysore (Karnataka). His father, N. Rama Rao, who had a BSc. (1931), joined the Mysore Educational Service and taught Physics and Mathematics in a High School, but he was Deputy Director of Education of the Karnataka State when he retired in 1968. Narayana Murthy, who refused to become a civil servant like one of his uncles, passed the entrance exam for the IIT but his father could not afford to pay the fees; therefore, in 1967, Murty graduated in Electrical engineering from the National Institute of Engineering at Mysore, and two years later, in 1969, he completed his MTech from IITKanpur. In 2011, Narayana Murthy quit as Chairman of the Board of Directors of Infosys, but the company was still in the hands of its founders: Senapathy K. Gopalakrishhnan (a Tamil Brahman from the Palkad district in Kerala) was Executive, co-Chairman of the Board and S. D. Shibulal the CEO and Managing Director. Shibulal, born in 1955 in Allapuzha, Kerala, was the only child of his father, an Ayurvedic doctor (but not from a Brahman caste, probably Ezhava which were traditionally tappers like the Nadar in Tamil Nadu), and mother a State employee of the Excise Department. He obtained a MSc. in Physics from the University of Kerala and later on, in 1989, a MSc. in Computer Science from Boston University. 


\section{The mid-size National software companies}

52 The second software capital cluster groups together 38 companies ( $40 \%$ of the panel) which are predominantly located on the upper-right quadrant of the diagram although they straddle axis 1 . Compared with the first class, these firms more distinctly represent the National software companies founded by engineering graduates and financed by indigenous capital. The top managers of these companies are defined negatively in terms of higher education, compared to cluster 1: no studies in prestigious institutions, with some exceptions, no MBA, no distinctions, and more graduates than post-graduates. The companies have a mid-market capitalization, they were founded in the years 1985 to 1995 and are younger than the Multinational of cluster 1, they are less CMM5 certified and their IT activities are more oriented towards the domestic market. Among these companies, we find a substantial number in which family members are on the Board of Directors (16 firms out of 38 ) while in the first clusters only 3 firms have family members sitting on the Board. In this cluster we find companies that operate in the technical education sector which is a typical domestic market.

One example of this cluster is Career Point, a medium player in the education sector founded in 1993. The company is present in this market from Kindergarten to Class XII, with a boarding school, but also in higher education, running two universities with engineering colleges plus a coaching center. Based at Kota (Rajasthan), Career Point was founded by Pramod Maheshwari ${ }^{16}$ who holds a Bachelor's of Technology (Textile) from IIT-Delhi. He is the CEO, Chairman and Managing Director of the company. Pramod Maheshwari hails from a Marwari merchant family of grain-dealers at Kota. They are a well-off family but are not among the big grain players of the place. In order to diversify their sources of revenue the family has opened two shops that sell electronic goods. After his graduation, Pramod Maheshwari wanted to go abroad to pursue his studies, but his close relatives wanted him to stay in Kota and join the family business. This perspective did not appeal to him and he turned to coaching when this sector was just developing in Kota at the end of the 1980s. The company drew $100 \%$ of its revenue from the domestic market, largely from Kota. Although listed on the NSE since 2010, Career Point is a family business run by Pramod and two of his three brothers. The Promoters group detains $60 \%$ of the equity-shares, but $53 \%$ is in the hand of the close relatives: father, mother, brothers and their wives. The concentration of shareholding is quite high: $0.3 \%$ only of the shareholders detain $88.5 \%$ of the value of the capital.

\section{The small-size companies with high qualified managers}

The third and last cluster groups also contains 38 companies ( $40 \%$ of the total). They are all located in the lower side of the diagram (the barycenter is plotted in the middle of the lower part of axis 2), which sets them apart from clusters 1 and 2 in terms of market capitalization, quite low for almost $70 \%$ of the firms in cluster 3. Yet, this cluster is spread along the first factor (axis 1), therefore it shares some active categories at work along this factor, on both side of axis 1.

The top executives in cluster 3 are characterized by their high credentials. They are far more educated even from those in cluster 1: $93 \%$ of the managers in cluster 3 are PostGraduates and $59 \%$ hold an MBA. If we consider this management degree as a resource 
that should differentiate "managers" from "owners" as a class, this distinction does not hold for the IT sector: $40 \%$ of the founders have an MBA, but $58 \%$ of the MBA holders are founders. Not only are the holders of a management degree well represented among the founders, but it seems that getting an MBA degree is a resource that is used for founding a company (assuming that the management degree has been obtained prior to the creation of the company, which is not always the case). Furthermore, 30\% of the managers studied abroad, mostly in the USA, and $81 \%$ of those who went abroad hold an MBA; this point emphasizes the fact that the main aim of going abroad was to get an MBA.

The vast majority of IT managers not only are new entrants into a new activity sector, but they started their professional career when the process of liberalization of the economy began. Considering the 60 managers out of 95 who are founders of their companies, $85 \%$ of them $(n=49)$ were born after 1953. If we assume that they were around 25 years old maximum when they graduated ${ }^{17}$ this means that they entered the field of the software industry from the end of the 1970s onwards. Among the 27 managers who graduated from a premium institution, only 18 founded their company and are still in command: 12 of them, born from 1952 to 1967, are 45 to 60 years old.

The economic categories that most differentiate the firms in cluster 3 from those in cluster 2 are their position on the IT market and their funding pattern. Two indicators are particularly significant. First, the firms in cluster 3 are clearly oriented towards the international IT market and second, for more than half of the companies, the Indian Public share is above $40 \%$, a rare situation for the firms in cluster 2; consequently, the portion of Foreign funds is below $20 \%$. Quite often, moreover, the companies in this cluster are not members of NASSCOM. At this stage of the research, it is difficult to go further in the differentiation of the firms: we need to know more about their activities and clientele to better understand their particular position on the IT market.

Megasoft is a good example of this cluster. The company was founded in 1994 by S. Ravindra Babu who was its managing director until 2012, but it was not registered with NASSCOM. Ravindra Babu, born in 1963, hails from an entrepreneurial family and belongs to the Reddy caste, one of the dominant agricultural castes of Andhra Pradesh. He completed his Bachelor's of science from the then Regional Engineering College of Tiruchirappalli, in Tamil Nadu, before going to the USA where he received various technical degrees, particularly an MTech in civil and environmental engineering from the Utah State University, but he has no MBA. Megasoft is a services provider of mobile solutions for banking payments whose activities are oriented towards the international market: only $6 \%$ of its global revenue is drawn from the domestic market. Megasoft is highly capitalized from the stock-market as its India Public share amounts to almost 50\% of its total equity-shares.

\section{Software capital: Brahmans and family business}

\section{The caste background of IT managers}

Table 7 gives the distribution of the top managers for the 3 clusters according to their castes, which we coded into 4 main groups. There are different ways of reading this table. We can say, first, that less than $30 \%$ of the managers are Brahmans, about $40 \%$ are nonBrahman high castes, and less than $30 \%$ are from other castes; or, second, that $67 \%$ of the managers are from upper castes, and that the merchant high castes constitute a 
minority (16\%) among these upper-caste managers. But the statistical results of the hierarchical classification we conducted shows that the category "Caste" would be significant only for the third cluster (Table 6), in this case the "Agricultural-Artisan" castes that we grouped below with "Others."

Table 8: Castes of the top managers of the software companies for the 3 clusters $(n=95)$

\begin{tabular}{|l|l|l|l|l|l|}
\hline Castes & Cluster 1 & Cluster 2 & Cluster 3 & Total & $\%$ \\
\hline Brahmans & 8 & 11 & 8 & 27 & 28 \\
\hline Merchant High Castes & 2 & 8 & 5 & 15 & 16 \\
\hline Non-Merchant High Castes & 4 & 13 & 5 & 22 & 23 \\
\hline Agri-Artisans \& Others & 5 & 4 & 18 & 27 & 29 \\
\hline Unknown & 0 & 2 & 2 & 4 & 4 \\
\hline Total & 19 & 38 & 38 & 95 & 100 \\
\hline
\end{tabular}

However the codification of caste is not a neutral procedure from a sociological viewpoint. Rejecting the State categories (SC, ST, $\mathrm{OBC}$ ) that were useless in this context, the groups we have coded are close to the varna categories, although they were not designed with this purpose. But in coding the Brahmans and the merchant castes separately, the sociologist is reproducing a previous legal category already codified in Hindu law, which singled out the Brahmans as a collective entity, therefore legitimizing the Hindu varna system of representation of the social world..$^{18}$ What do we intend to do sociologically with the category of caste? Quite often, it is implicitly used in the place of missing data regarding the credentials and profession of the parents. Yet, the relationship between caste (whatever its definition) and the socio-economic characteristics of family is often either misleading or difficult to interpret, nor is it straightforward.

61 If we assume that the Brahmans, as a collective entity, would represent about $4 \%$ of the total Hindu population, ${ }^{19}$ they are overrepresented among the top executives of the IT sector, according to our survey, as they would probably be in many other professions. To overcome the statistical limitation of our data, we can focus on a case study that will help us to raise a few more questions regarding this issue. Let us consider Tata Consultancy Services (TCS), a firm whose recent developments have been documented by Subramaniam Ramadorai (2011) who retired as CEO in 2009 after 37 years of service, and then became vice-chairman of the Board of Directors. Ramadorai is a Tamil Brahman born in 1945 at Nagpur (Maharashtra), where his maternal grandfather settled when he retired from the Posts and telegraph audit department in Bombay. His paternal family came from a village in the south of Tamil Nadu where his paternal grandfather was village accountant, but his father was a civil servant who retired as accountant general of Tamil Nadu at Chennai.

Ramadorai, who grew up in Delhi, graduated in physics from the University of Delhi, then did a Master's degree in electronics and communications at the Indian Institute of Science 
at Bangalore, before going to the University of California Los-Angeles in the US where he finally completed his $\mathrm{PhD}$ in computer sciences. These three complementary degrees gave Ramadorai a strong scientific background to start his professional career in the IT industry. Although he had the opportunity to stay in the USA, Ramadorai decided to come back to Indian and, in 1972, he was recruited as a software engineer at TCS by F. C. Kholi (a Punjabi born in 1924 in Peshawar, now in Pakistan), then the general director of the company.

Among the top executives of TCS, we find Tamil Brahmans closely connected by caste, kinship and alliance. Seturaman Mahalingam, born in 1948, is a qualified Chartered Accountant who holds a degree in commerce; he joined TCS in 1970, two years before Ramadorai, and became Chief Financial Officer in 2012. Mahalingam and Ramadorai's ancestors came from the same region in Tamil Nadu, but they do not belong to the same Brahman sub-caste (Fuller and Narasimhan 2014:89-90). Another top manager was N. Ganapathy Subramanian executive vice-president of TCS and head of TCS Financial Solution; in 2014 he was appointed additional director and chairman of the board of TataElxi where he took over the role of Ramadorai who stepped down at the age of $70 . \mathrm{N}$. Ganapathy Subramaniam, who entered TCS at the beginning of the 1970s, is an older brother of Natarajan Chandrasekaran who was Chief Operating Officer at TCS (TCS 2009:46) in 2008. Natarajan Chandrasekaran was born in 1963 in a Tamil Brahman family; his father (Srinivasan Natarajan) was a lawyer in the Madras High Court and also held a farm in the Cavery basin of Tamil Nadu. He obtained a BSc in Applied Sciences from the Coimbatore Institute of Technology before completing a Master's in Computer Application (a degree quite rare at the time) from the then Regional Engineering College of Tiruchirappalli in Tamil Nadu. After he did an internship at TCS in 1986, he joined the company as a software engineer the next year, in 1987, and 22 years later, in 2009, he succeeded Ramadorai as CEO of TCS. In January 2017 Natarajan Chandrasekaran was named Chairman of Tata Sons, while his older brother N. Ganapathy Subramaniam became Chief Operating Officer of TCS. There is no family relationship between Natarajan Chandrasekaran and S. Ramadorai (TCS 2009:46). ${ }^{20}$

64 Are these individual cases significant from a sociological viewpoint? Historians of Modern India have underlined the fact that the Tamil Brahmans at Madras, during the colonial period, were closely connected and functioned like a clique. ${ }^{21}$ It whould be worth historicizing this network and extending its study after Independence in order to see if this mode of networking stopped with the end of colonial rule. TCS should be a good case in point because the concentration of South Indian employees seems higher in this company than at Infosys, Wipro or HCL for example. ${ }^{22}$

\section{Brahmans and merchants}

According to some socioeconomic studies, three fourths of the 400 estimated largest companies in India, called business groups, would be a family business with a strong caste background among merchant communities (Chakraborty 2011). But what do we mean by family business in regards to the software companies we have studied?

The presence of family members on the board of directors can be considered as an indicator of a family business. In this regard, almost all the 35 family-business firms of the panel (37\%) are distributed equally between clusters 2 and 3. Among the biggest companies (cluster 1), only 3 firms have family members on their board of directors: 
eClerx, Persistent Systems and Hinduja Global Solutions, this last one being part of the Hinduja group founded by a Sindhi Hindu family, and now based in London. Yet, a firm whose family members do not sit on the Board of Directors can nevertheless be under the control of the promoters group in which the founder might have the main share. The typical example would be Azim Premji at Wipro.

Furthermore, 12 out of the 35 family-business IT companies are run by managers who are from non-merchant castes, the remaining 23 family-business firms being equally spread among the other groups. In other words, the companies founded or run by managers who hailed from merchant communities are not necessarily organized according to the family-business model. But we should notice that some business groups run by old merchant families were among the first companies which had foreseen the development of IT technologies and had diversified their activities quite early, like DCM, Tata, or Patni Computer Systems (Subrahmaniam 2014).

The fact remains that the opposition between the family-business firms and the major software companies like TCS, Infosys, Wipro or HCL is a common view endlessly repeated by people who might have some well-founded reason for defending this representation of the software industry. Nandan Nilekani, one of the founders of Infosys, recalled that Narayana Murthy and the engineers who parted from Patni Computer Systems, in 1981, wanted to develop, he said, an "un-Marwari company" (Sanghvi 2007:1-10). Vir Sanghvi, the journalist who conducted the interview, added: "By this they meant ... employees should be treated with respect; no bribes will be paid; there will be no cash transaction." Narayana Murthy and his colleagues could not stand "the typical Marwari-bania business ethic of that era' wrote Vir Sanghvi. Stressing the number of South Indian Brahmans among the founders of Infosys, the journalist added: "Infosys represented the revolt of South Indian Brahmans against the North Indian Banias who dominated Indian business at the time." Whether Vir Sanghvi expressed the unspoken view of Nandan Nilekani (who professed memory loss about what he said), whether the founding of Infosys could be understood as a revolt or not against North Indian Banias, this is not the issue here. At the very least, this saying points to an opposition between traditional merchant groups who are accustomed to doing business, whatever the sector of activities, and new comers into the economic market, for whom values and ethic could be mobilized as a resource in order to legitimate the place they have to find for themselves.

But what is significant is that the dominant view of the software industry has been developed by the major companies, particularly through NASSCOM, although there socioeconomic characters set them quite apart from the other IT companies listed on the NSE. Infosys itself is a software firm quite different from TCS and Wipro. It is not part of a conglomerate; it is a new player on the economic market; its share of the Promoters groups is not very big; its percentage of Indian Public Funds is quite significant, and although branded as an Indian company, which it is, Infosys has more than half of its shareholding held by Foreign Funds. Moreover, the management of the company is more in tune with that of its American competitors than with a so-called Indian merchant family-business. For all these reasons, it is understandable that the representation of the software industry projected by these major IT firms, and Infosys in particular, has become the dominant view of this services sector, in India but also outside India where the main clients of these Indian Multinational companies are located. 


\section{Conclusion}

70 In studying the structure of Indian software capital, combining biographical data of the top managers with socioeconomic information on the IT companies, our aim was to break with the nebulous view of the software industry that has prevailed among scholars. Considering the first hundred software companies listed on the NSE, some sound conclusions can be summarized. There is a three-tier concentration of software capital, first, in the hands of the tiny group of the Indian Multinational companies, second, among the Promoters groups, which are the main shareholders in most of the companies, and third, within the holders of shares of the highest size and value, whatever the companies are. Moreover there is not a single Indian IT firm, in the panel, without foreign funding. Consequently, the Multinational Indian software companies and their managers are as Transnational as the start-ups located in the niches of the high technological sectors of the IT market. But what differentiates the Indian software companies is their access to the international IT market according to their economic strength and their level of professionalization.

71 This survey also breaks with the general view that the software entrepreneurs or top managers are all highly-educated people who graduated from elite engineering colleges. This is true only for less than a quarter of them who are concentrated either in the biggest IT companies or in smaller ones. Otherwise, there is a clear divide between these managers who cumulate studies abroad, post-graduate degrees, and diplomas in management with those engineers who are just graduates but might be as successful as other managers.

72 Finally, combining these sets of data, we have differentiated 3 main clusters that constitute the space of Indian software capital: first the Multinational Indian companies, second, the middle-size national firms oriented predominantly towards the domestic market, third and lastly, the small companies founded or managed by highly educated executives.

73 At this stage of the research, however, the results should be qualified and a couple of issues need to be raised. The results presented in this article have at least three main limitations. Firstly, regarding the sociodemographic profile of the top managers, we require better knowledge of their family background in terms of occupation and education of the parents. Otherwise it is meaningless to consider the caste origin as a proxy for these two socio-demographic variables (the example of Shiv Nadar at HCL is a good case in point). But the grammar of caste within the IT industry should be reconsidered in order to better understand the practice of networking among the top managers. Secondly, the understanding of software capital should be coupled with an analysis of the labor force of the IT companies. But quantitative data are scarce as very few companies detail the origins and educational background of their employees, and so far we have had to rely on qualitative study (Upadhya 2016). Finally, the main limitation of this survey might be the filter we have used, which is the NSE itself. It is clear that we know little about the small and medium enterprises that have not yet gone public whether they work for the domestic or the international IT market, like high-tech startups (Parthasarathy and Aoyama 2006). But the main difficulty remains the access to reliable sources on those firms. In any case, this study of the first hundred major firms of 
the IT sector should give us a reference point from which we should be able extend our knowledge of Indian software capital.

Annexe - Table 9: The software companies and their top managers selected for the MCA according to their cluster $(n=95)$

\begin{tabular}{|c|c|c|c|c|c|}
\hline Cluster & $\begin{array}{l}\text { Company } \\
\text { (Active) }\end{array}$ & Top Manager & Cluster & $\begin{array}{l}\text { Company } \\
\text { (Active) }\end{array}$ & Top Manager \\
\hline 1 & Core ET & Sanjeev Mansotra & 2 & Prime Focus & Naresh Malhotra \\
\hline 1 & eclerx & P. D. Mundhra & 2 & Ramco & P R Venketrama Raja \\
\hline 1 & Firstsource & Shailesh J. Mehta & 2 & Software Tech & Yogesh C.Vaidya \\
\hline 1 & $\begin{array}{l}\text { HCL } \\
\text { Technology }\end{array}$ & Shiv Nadar & 2 & Spanco & Kapil Puri \\
\hline 1 & $\begin{array}{l}\mathrm{HCL} \\
\text { Infosystems }\end{array}$ & Ajai Chowdry & 2 & Take Solutions & Sivan Sridharan \\
\hline 1 & Hexaware & P.R. Chandrasekar & 2 & Usha Martin & Prashant Jhawar \\
\hline 1 & $\begin{array}{l}\text { Hinduja } \\
\text { Solutions }\end{array}$ & Partha DeSarkar & 2 & Vakrangee & Dinesh Nandwana \\
\hline 1 & Infosys & S. D. Shibulal & 2 & Zenith Info & Akash Saraf \\
\hline 1 & $\begin{array}{l}\text { Infotech } \\
\text { Entrp }\end{array}$ & B.V.R. Mohan Reddy & 3 & Acropetal & D. Ravi Kumar \\
\hline 1 & Mindtree & $\begin{array}{l}\text { Krishnakumae } \\
\text { Natarajan }\end{array}$ & 3 & Aftek & Ranjit Dhuru \\
\hline 1 & Mphasis & Balu Ganesh Ayyar & 3 & Bartronics & Sudhir Rao \\
\hline 1 & Onmobile & Arvind Rao & 3 & Compuage & Atul H. Mehta \\
\hline 1 & $\begin{array}{l}\text { Persistent } \\
\text { System }\end{array}$ & Anand S. Deshpande & 3 & Cyber Media & Pradeep Gupta \\
\hline 1 & $\begin{array}{l}\text { Polaris } \\
\text { Software }\end{array}$ & Arun Jain & 3 & Cybertech & Viswanath Tadimety \\
\hline 1 & Rolta & Kamal K. Singh & 3 & Educomp & Shantanu Prakash \\
\hline 1 & TCS & N. Chandhrasekaran & 3 & FCS Software & Dalip Kumar \\
\hline 1 & $\begin{array}{l}\text { Techno } \\
\text { Electric }\end{array}$ & $\begin{array}{ll}\text { Padam } & \text { Prakash } \\
\text { Gupta } & \end{array}$ & 3 & Four Soft & $\begin{array}{ll}\text { Palem } & \text { Srikanth } \\
\text { Reddy } & \end{array}$ \\
\hline 1 & Wipro & T. K. Kurien & 3 & Glodyne & Annand Sarnaaik \\
\hline
\end{tabular}




\begin{tabular}{|c|c|c|c|c|c|}
\hline 1 & Zensar & Ganesh Natarajan & 3 & GSS Infotech & Bhargav Marepally \\
\hline 2 & $3 \mathrm{i}$ Infotech & V. Srinivasan (NRI) & 3 & HOV Services & Sunil Rajadhyaksha \\
\hline 2 & $\begin{array}{l}\text { Accel } \\
\text { Frontline }\end{array}$ & N. R. Panicker & 3 & LCC Infotech & Kirti Lakhotia \\
\hline 2 & AGC Networks & Satya Kumar Jha & 3 & Megasoft & G. V. Kumar \\
\hline 2 & Allsec Tech & R. Jagadish & 3 & Melstar & Richard D'Souza \\
\hline 2 & Aptech & Ninad Karpe & 3 & Panoramic Univ & Arun B. Tari \\
\hline 2 & Aurionpro & Amit Sheth & 3 & Prithvi Info & $\begin{array}{l}\text { Vuppalapati Satish } \\
\text { Kumar }\end{array}$ \\
\hline 2 & Blue Star & Sunil Bhatia & 3 & Quintegra & $\begin{array}{l}\text { Vaidynathan } \\
\text { Sriraman }\end{array}$ \\
\hline 2 & Career Point & Pramod Maheshwari & 3 & R Systems Inter & $\begin{array}{l}\text { Satinder Singh } \\
\text { Rekhi }\end{array}$ \\
\hline 2 & Compucom & $\begin{array}{l}\text { Surendra Kumar } \\
\text { Surana }\end{array}$ & 3 & RS Software & Rajnit Rai Jain \\
\hline 2 & Datamatics GS & Lalit S. Kanodia & 3 & Saksoft & Aditya Krishna \\
\hline 2 & EdServ & S. Giridharan & 3 & Sasken Comm & Rajiv Mody \\
\hline 2 & Everonn & Susha John & 3 & Smartlink & Kamalaksha R. Naik \\
\hline 2 & $\begin{array}{l}\text { Financial } \\
\text { Tech }\end{array}$ & Jignesh Shah & 3 & Sonata Software & P. Srikar Reddy \\
\hline 2 & Genesys & Sajid Malik & 3 & Tanla Solutions & D. U. Kumar Reddy \\
\hline 2 & Geodesic & Kiran P. Kulkarni & 3 & Thinksoft & A V Asvini Kumar \\
\hline 2 & Geometric & $\begin{array}{l}\text { Manu } \quad \text { Mahmud } \\
\text { Parpia }\end{array}$ & 3 & Trigyn & R. Ganapathi \\
\hline 2 & $\begin{array}{l}\text { Hinduja } \\
\text { Ventures }\end{array}$ & Ashok P. Hinduja & 3 & Zicom & Manohar Bidaye \\
\hline 2 & India Infoline & $\begin{array}{l}\text { Nirmal Bhanwarlal } \\
\text { Jain }\end{array}$ & 3 & Zylog & $\begin{array}{l}\text { Sudarshan } \\
\text { Venkatraman }\end{array}$ \\
\hline 2 & Infinite Comp & Upinder Zutshi & Cluster & Companies (Sup.) & Top Manager \\
\hline 2 & $\begin{array}{l}\text { Info-Drive } \\
\text { Soft }\end{array}$ & K. Chandrasekaran & 2 & Tamilnadu Telec & V.S. Parameswaran \\
\hline 2 & IntraSoft Tech & Arvind Kajaria & 3 & Allied Digital & Nitin D. Shah \\
\hline
\end{tabular}




\begin{tabular}{|l|l|l|l|l|l|}
\hline 2 & KPIT & Kishor Patil & 3 & Elnet Tech & $\begin{array}{l}\text { Unnamalai } \\
\text { Thiagarajan }\end{array}$ \\
\hline 2 & Mastek & Sudhakar Ram & 3 & Gemini & $\begin{array}{l}\text { Ramamurthy } \\
\text { Vijaykumar }\end{array}$ \\
\hline 2 & Micro Tech & P. Sekhar & 3 & Helios\&Matheson & G. K. Muralikrishna \\
\hline 2 & $\begin{array}{l}\text { Mirc } \\
\text { Electronics }\end{array}$ & Gulu L. Mirchandani & 3 & ICSA & G. Bala Reddy \\
\hline 2 & Net 4 India & $\begin{array}{l}\text { Jasjit } \\
\text { Sawhney }\end{array}$ & 3 & Kernex Micro & Colonel L.V. Raju \\
\hline 2 & Omnitech & Atul Hemani & 3 & Spectacle Info & Tejesh Kodali \\
\hline 2 & Onward & Harish S. Mehta & 3 & TVS Electronics & S. S. Raman \\
\hline
\end{tabular}

\section{BIBLIOGRAPHY}

Arora, Ashish and Suma Athreye. 2002. "The Software Industry and India's Economic Development." Information Economics and Policy 14: 253-73.

Bairy T. S., Ramesh. 2010. Being Brahman, Being Modern: Exploring the Lives of Caste Today. Delhi: Routledge.

Balasubramanian, N and R. V. Anand. 2013. Ownership Trends in Corporate India 2001-2011: Evidence and Implications. IIM-Bangalore, Working Paper 49.

Bourdieu, Pierre and Monique de Saint-Martin. 1978. "Le Patronat." Actes de la recherche en sciences sociales 20-21: 3-82.

Bourdieu, Pierre. 1979. La distinction: Critique sociale du jugement. Paris: Éditions de Minuit. English 2010. Distinction: A Social Critique of the Judgment of Taste. London and New York: Routledge.

Bourdieu, Pierre. 1999. "Une révolution conservatrice dans l'édition." Actes de la recherche en sciences sociales 126-127: 3-28. English 2008. "A Conservative Revolution in Publishing." Translation Studies 1(2): 123-53.

Bourdieu, Pierre. 2000. Les structures sociales de l'économie. Paris: Éditions du Seuil. English 2005. Social Structures of the Economy. Cambridge: Polity Press.

Bourdieu, Pierre. 2016. Sociologie générale. Vol. 2, Cours au Collège de France 1983-1986. Paris: Éditions du Seuil. 
Chakraborty, Indrani. 2011. "Does Capital Structure Depend on Group Affiliation? An Analysis of Indian Corporate Firms?” Kolkata: Institute of Development Studies, Occasional Paper 29.

Davis, Kingsley. 1951. The Population of India and Pakistan. Princeton: Princeton University Press.

Deshpande, Ashwani. 2011. The Grammar of Caste: Economic Discrimination in Contemporary India. Delhi: Oxford University Press.

Fuller, C. J. 2011. "The Modern Transformation of an Old Elite: The Case of the Tamil Brahmans." Pp. 80-97 in A Companion to the Anthropology of India, edited by I. Clark-Decès. Malen, MA: WileyBlackwell,

Fuller, C. J. and Haripriya Narasimhan. 2014. Tamil Brahmans: The Making of a Middle-Class Caste. Chicago and London: The University of Chicago Press.

Haldar, Arunima and S. V. D. Nageswara Rao. 2011. "Empirical Study on Ownership Structure and Firm Performance.” Indian Journal of Corporate Governance 4(2) (https://papers.ssrn.com/sol3/ papers.cfm?abstract_id=2185860)

Hardgrave Jr., Robert L. 1969. The Nadars of Tamilnadu: The Political Culture of a Community in Change . Bombay: University of California Press, Oxford University Press.

Harris, John. 2003. "The Great Tradition Globalises: Reflections on Two Studies of 'The Industrial Leaders' of Madras.” Modern Asian Studies 37(2): 327-62.

Heeks, Richard. 1996. India's Software Industry: State Policy, Liberalization and Industrial Development. New Delhi: Sage Publications.

Jain, Tarun. 2006. Corporate Shareholding Pattern: An Analysis of the Changing Perspective in the Indian Capital Markets (http://ssrn.com/abstract=1087394).

Khanna, Tarun and Krishna G. Palepu. 2004. "Globalization and Convergence in Corporate Governance: Evidence from Infosys and the Indian Industry." Journal of International Business Studies 35: 487-507.

Khanna, Tarun and Krishna G. Palepu. 2005. "The Evolution of Concentrated Ownership in India: Broad Patterns and a History of the Indian Software Industry." Pp. 283-324 in A History of Corporate Governance around the World: Family Business Groups to Professional Managers, edited by R. K. Morek. Chicago: University of Chicago Press.

Lardinois, Roland, with P. Vignesh Illavarasam. 2014. Le secteur des technologies de l'information et de la communication en Inde. Paris: Association pour l'Emploi des Cadres, Les études de l'emploi cadre (https://jd.apec.fr/files/live/mounts/media/medias_delia/documents_a_telecharger/ etudes_apec/le_secteur_des_tic_en_inde/40a16f6e9e437cb3ac02da07403d2209.pdf).

Lebaron, Frédéric. 2006. L'enquête quantitative en sciences sociales: Recueil et analyse des données. Paris: Dunod.

Leroux, Brigitte and Henry Rouanet. 2010. Multiple Correspondence Analysis. Thousand Oaks: Sage Publications.

Leducq, Divya. 2009. "La diffusion spatiale de l'informatique en Inde. De la nation au Kérala." Echogéo 10 (http://echogeo.revues.org/11355)

Leducq, Divya. 2009. "Secteur TIC et refonte de la gouvernance urbaine: une réflexion sur les nouveaux acteurs de Pune." Networks and Communication Studies, NETCOM 23(3-4): 221-44.

NASSCOM. 2015. The IT-BPM Sector in India: Strategic Review. New Delhi. 
Mani, Dahlia and James Moody. 2014. "Moving beyond Stylized Economic Networks Models: The Hybrid World of the Indian Firms Ownership Network." American Journal of Sociology 119(6): 162969.

Naudet, Jules, Claire-Lise Dubost. 2016. "The Indian Exception: The Densification of the Network of Corporate Interlocks and the Specificities of the Indian Business System (2000-2012)." SocioEconomic Review, January 27, pp. 1-30.

Naudet, Jules, Adrien Allorant and Mathieu Ferry. Forthcoming. "Heirs, Corporate Aristocrats and 'Meritocrats': The Social Space of Top CEOs and Chairmen in India." Socio-Economic Review.

Parthasarathy, Balaji. 2004. "Globalizing Information Technology: The Domestic Policy Context for India's Software Production and Exports." Iterations: An Interdisciplinary Journal of Software History 3: 1-38.

Parthasarathy, Balaji and Yuko Aoyama. 2006. "From Software Services to R\&D Services: Local Entrepreneurship in the Software Industry in Bangalore, India." Environment and Planning 38: 1269-85.

Rajan, Kaushik Sunder. 2006. Biocapital: The Constitution of Postgenomic Life, Durham and London: Duke University Press.

Ramadorai, Subramaniam. 2011. The TCS Story... and Beyond. New Delhi: Penguin.

Saith, Ashwani, M. Vijayabaskar and V. Gayathri. 2008. ICTs and Indian Social Change: Diffusion, Poverty, Governance. New Delhi: Sage.

Sanghvi, Vir. 2007. Men of Steel: India's Business Leaders in Candid Conversation. Delhi: Roli Book. Sharma, Dinesh C. 2009. The Long Revolution: The Birth and Growth of India's IT Industry. New Delhi: HarperCollins.

Sharma, Dinesh C. 2015. The Outsourcer: The Story of India's IT Revolution. Cambridge, MA: The MIT Press.

Subramanian, Ramesh. 2014. "Technology Policy and National Identity: The Microcomputer Comes to India." IEEE, Annals of the History of Computing 36(3): 19-29.

Tawiah, Vincent Konadu and Mudaheranwa Benjamin. 2014. "Who Owns Indian Companies? A Decade of Shareholding Patterns of Automobile and IT Industry." IOSR, Journal of Business and Management 16(10) (http://ssrn.com/abstract $=2534899)$.

TCS. 2009. Tata Consultancy Services Annual Report 2008-2009, Mumbai.

Tripathi, Dwijendra, Jyoti Jumani. 2013. The Oxford History of Contemporary Indian Business. New Delhi: Oxford University Press.

Upadhya, Carol. 2004. "A New Transnational Capitalist Class? Capital Flows, Business Networks and Entrepreneurs in the Indian Software Industry." Economic and Political Weekly, 39(48): 5141-43 and 5145-51.

Upadhya, Carol (2016) Reengineering India: Work, Capital, and Class in an Offshore Economy. Delhi: Oxford University Press.

Upadhya, Carol and A. R. Vasavi. 2008. In an Outpost of a Global Economy: Work and Workers in India's Information Technology Industry. New Delhi: Routledge.

Washbrook, David A. 1977. The Emergence of Provincial Politics: The Madras Presidency 1870-1920. Cambridge: Cambridge University Press. 


\section{NOTES}

1. IT Enabled Services include Business Process Outsourcing (BPO) and Business Process Management (BPM).

2. The literature review has been limited to the works most closely related with our field and subject, whether on the software industry or on caste issues.

3. Commonly called Baniya, particularly by their non-merchant competitors, people from these traditional merchant groups feel that the term is slightly derogatory and they prefer to call themselves Vaish, designating the varna of the Vaishya, a term widely used in the press in Hindi when presenting the caste background of candidates in local elections for example.

4. The definition of "software capital" I propose in this article, differs from the sociocultural approach developed by Rajan (2006).

5. For running the Multiple Correspondence Analysis I have used SPAD software. The results presented here can be considered as the most coherent I obtained considering the categories selected. The population studied is a panel of the software companies listed on the NSE and not a sample, in the probabilistic meaning of the term, of all the software companies listed.

6. I follow Le Roux and Rouanet who used the "modified rated" defined by J. P. Benzécri in order to better appreciate the contributions of the first principal axes to the construction of the clouds of points (see Le Roux and Rouanet 2010:39).

7. The under-representation of women is also high among the top managers; there is only $7.6 \%$ of women among the 882 top managers of Tata Consultancy Services, the only company that mentions the gender of its managers (see TCS 2009:32-46).

8. Muslims are also under-represented in the software industry: less than $1 \%$ of the top managers at TCS are Muslims (see TCS 2009:32-46); according to the Annual Activity Reports of the other companies, 2,5\% (3 out of 120) of the top managers at Wipro are Muslims, and not a single one, it seems, at Infosys and HCL in 2012.

9. For a comparison with the profile of the chairmen and CEO of the top 100 companies listed on the NSE, see Naudet, Allorant and Ferry (forthcoming).

10. Among the 95 software companies we studied 12 mentioned CMM5 certification in their Annual Activity Report for 2012. This professional certification remains highly distinctive. According to different authors, in 2002-2003 the total number of Indian companies that had CMM5 certification varied between 65 and 85 (Parthasarathy and Aoyama 2006:1271, Upadhya 2016:121).

11. In the panel I studied, 8 companies have foreign promoters who represent $0.7 \%$ of the total promoters group; they have been included in the group "Foreign Institutions."

12. The structure of the Promoters group and the way it exercises its control can be quite complex for the biggest companies, but we do not consider this issue in this article.

13. The breakdown of the shareholding pattern in the activity reports of the companies did not allow us to go beyond the distinction of the shareholding into 3 main classes. The value of shareholding is estimated using the mean market capitalization of the companies for the fiscal years 2002-2003 to 2011-2012.

14. See "The Amazing Story of the Birth of HCL" in Rediff India Abroad, June 9, 2007. Retrieved December 23, 2016 (http://www.rediff.com/money/2007/jun/09bspec1.htm).

15. More exactly, Shiv Nadar's ancestors belong to a sub-caste of the Nadar, the Nadan, who were owners of land, well-off economically, and who accessed English education at the beginning of the $20^{\text {th }}$ century; his maternal uncle S. B. Adityan or Adithan (born in 1905) who founded the Tamil daily, Dina Thanthi, completed his MA from the University of Madras and studied law at the Middle Temple in London (see Hardgrave Jr. 1969:39). 
16. Personal interview with Pramod Maheshwari, Kota, September 30, 2014.

17. The mean age of entry in the IT industry, observed from the list of the top managers we collected for TCS, Infosys and Wipro $(n=1018)$ is roughly 22 to 25 years.

18. On the sociological effect that involves any codification of the professions (or here the caste), see Bourdieu (2016: 226-27).

19. See Davis (1951). In 2011, the Tamil Brahmans population was estimated at about $2.5 \%$ of the total population of the Tamil Nadu State, see Fuller and Narasimhan (2014:231-41). On the opposite side of the Indian social order, Untouchables were estimated at $14 \%$ of the total population of India in 1931.

20. Yet, while I was doing fieldwork at Chennai in 2012, people (who were not Brahman) told me that Natarajan Chandrasekaran could be, for some, the "son-in-law," for other, the "brother-inlaw" of Ramadorai, statements that circulate on the net as well. This hearsay evidence is difficult to interpret. It might express an anti-Brahman feeling aroused by the high number of Tamil or South-Indians employees at TCS, among whom many are probably Brahmans, but it also underlines the strength of the caste and kinship model which is mobilized by people in order to make sense of the overrepresentation of the Brahmans, here at TCS, whether this overrepresentation is factually grounded or not. The Tamil Brahmans, nicknamed "Tambrahms" both by outsiders and insiders, have a singular historical trajectory compared to other groups of Brahmans in contemporary India, see Fuller and Narasimhan, in particular chapter 7 (2014: 21129).

21. On the struggles for control of the modes of the patronage system in colonial South-India, see Washbrook (1977).

22. Among the 882 top managers listed at TCS in 2009 under the Particular of Employees Act, at least $25 \%$ have a South-Indian name (see TCS 2009).

\section{ABSTRACTS}

The aim of this article is to study Indian software capital considered as the nexus of IT companies and their top managers. For this purpose, we have conducted a Multi Correspondence Analysis of a set of data collected for the first hundred IT firms listed on the National Stock Exchange in Mumbai in 2012. We address three main research questions. Firstly, what is the sociodemographic profile of these entrepreneurs, secondly, what is the shareholding pattern of these companies and their position on the IT market and, lastly, what are the differences between these IT companies and traditional business groups? Although the managers are highly educated and share the same technical culture, the results show a clear division of software capital in 3 clusters. First, the Multinational companies, which are the oldest firms and the biggest in terms of manpower and global revenue, are opposed to a second group of IT companies founded or managed by executives who are mainly graduates, and whose activities are oriented towards the domestic market; lastly, a third group of companies run by highly-qualified managers (with MBAs) combined characters of clusters 1 and 2, but are smaller companies more dependent on the stock-market. In the software industry, the family-business model, which is not specifically related to the merchant high castes, is well represented, except for the Indian MNCs, but with some qualifications. 
INDEX

Keywords: Brahman, castes, elite, entrepreneurs, IT (Information Technology), Multi Correspondence Analysis (MCA), shareholding

\section{AUTHOR}

ROLAND LARDINOIS

Centre national de la recherche scientifique, Centre d'études de l'Inde et de l'Asie du sud (EHESS) 